\title{
Propuesta de introducción de nuevos tipos de arrendamientos de vivienda en el Código Civil ${ }^{*}$
}

\author{
Proposal for the introduction of new types of housing leases in the Civil Code
}

\author{
ISABEL L. MARTENS JIMÉNEZ \\ Investigadora Predoctoral y miembro de la REDVIFAM** \\ Universidad de Málaga (España) \\ martens@uma.es
}

https://orcid.org/0000-0003-2896-6416

Resumen: En este artículo se acomete el estudio y la revisión crítica de los distintos tipos de arrendamientos que recaen sobre una vivienda existentes en nuestro ordenamiento jurídico y su adecuación a la realidad social imperante en la actualidad. Asimismo, se analiza la adecuación y suficiencia de la regulación prevista por el legislador español para atender a las nuevas modalidades de arrendamiento que han surgido en la práctica o que han tenido un mayor auge en la actualidad. Sobre la base del Derecho arrendaticio alemán, como modelo de un sistema arrendaticio jurídicamente seguro y atractivo para los ciudadanos, se ofrecen propuestas legislativas que suponen una importante modificación de nuestro sistema arrendaticio.

Cómo citar este trabajo: MARTENS JIMÉNEZ, Isabel L., "Propuesta de introducción de nuevos tipos de arrendamientos de vivienda en el Código Civil", Revista de Estudios Jurídicos y Criminológicos, n. ${ }^{\circ}$ 4, Universidad de Cádiz, 2021, pp. 49-101, DOI: https://doi.org/10.25267/REJUCRIM.2021.i.4.04

* Este trabajo se ha realizado en el ámbito del Proyecto de investigación "Los alojamientos turísticos contratados entre particulares en plataformas colaborativas", dentro del programa FEDER Andalucía 20142020, dirigido por Moreno-Torres Herrera y Gálvez Criado (UMA-18-FEDERJA-132). En cuanto a la investigación del arrendamiento alemán, es fruto de la estancia de investigación realizada durante los meses de febrero a abril de 2020 en la Universidad de Colonia, gracias a la financiación concedida en el seno del Plan Propio de la Universidad de Málaga.

** Red de investigación temática "Vivienda y familia en el siglo XXI", coordinada por Cervilla Garzón y financiada por el Programa estatal de generación de conocimiento y fortalecimiento científico y tecnológico del sistema I+D+i, acciones de dinamización de "Redes de investigación", convocatoria de 2018 (Ref: RED2018-102339-T). 
Palabras claves: arrendamiento, vivienda habitual, vivienda turística, arrendamiento turístico, arrendamiento de temporada, arrendamiento compartido, arrendamiento por habitaciones, arrendamiento colaborativo.

Abstract: This article undertakes the study and critical review of the different types of leases of housing existing in our legal system and their adequacy to the prevailing social reality at present. It also analyses the adequacy and sufficiency of the regulation envisaged by the Spanish legislator to address the new types of leases that have arisen in practice or which have reached a greater number at present. On the basis of German tenancy law, as a model of a legally secure and attractive tenancy system for citizens, legislative proposals are offered which represent an important modification of our tenancy system.

Keywords: lease, habitual residence, tourist accommodation, tourist rental, seasonal lease, shared rental, room rental, co-housing, co-living.

Sumario: 1. INTRODUCCIÓN. 2. LOS DISTINTOS TIPOS DE ARRENDAMIENTOS DE VIVIENDA EN EL ORDENAMIENTO JURÍDICO ESPAÑOL. REFLEXIONES SOBRE SU ADECUACIÓN A LA REALIDAD ACTUAL. 2.1. Arrendamientos de vivienda en la legislación española. 2.1.A. Arrendamiento de vivienda habitual o de necesidad permanente de vivienda. 2.1.B. Arrendamiento de vivienda no habitual o de necesidad transitoria de vivienda. 2.1.C. Arrendamiento de vivienda turística. 2.2. La inadecuación de los tipos de arrendamientos de vivienda a la realidad actual y la inadecuación de su regulación. 2.2.A. Un solo arrendamiento de vivienda habitual, un solo arrendatario y un solo modelo de convivencia. 2.2.B. El arrendamiento de la vivienda habitual por varios arrendatarios. 2.2.C. El arrendamiento de habitaciones con derecho a usar zonas comunes. 2.2.D. Cooperativas de vivienda en régimen de cesión de uso. 2.2.E. El arrendamiento de vivienda no habitual. El denominado "arrendamiento de temporada". 2.2.F. El arrendamiento de vivienda turística. 3. LOS TIPOS DE ARRENDAMIENTOS DE VIVIENDA EN EL DERECHO ALEMÁN. 3.1. El arrendamiento de vivienda que sea el centro de la vida del individuo: principales medidas proteccionistas. 3.1.A. Las causas de extinción del contrato y el derecho de oposición del arrendatario. 3.1.B. La limitación a la elevación de la renta vigente el arrendamiento y el límite a la libre determinación inicial de la renta. 3.2. Otros tipos de arrendamientos que recaen sobre la vivienda: el $\S 549$ BGB. 3.2.A. Arrendamiento temporal de vivienda. 3.2.B. Arrendamiento de vivienda amueblada y compartida con el arrendador. 3.2.C. Vivienda arrendada por una persona jurídica de Derecho público o privado que subarriende a una persona con urgente necesidad de acceder a una vivienda. 3.2.D. Arrendamiento de habitaciones en una residencia de estudiantes o jóvenes. 3.2.E. El arrendamiento de viviendas a los empleados del arrendador. 3.3. Conclusión sobre el Derecho alemán. 4. PROPUESTA DE INTRODUCCIÓN DE NUEVOS TIPOS DE ARRENDAMIENTOS DE VIVIENDA EN EL CÓDIGO CIVIL Y LÍNEAS GENERALES DE SU REGULACIÓN. 5. CONCLUSIONES. 6. BIBLIOGRAFÍA.

\section{INTRODUCCIÓN}

Todo parece indicar que, pese a los intentos del legislador español -de los que son buena muestra las reformas de 2013, 2018 y $2019^{1}$ mediante las que se modificó la Ley 29/1994,

\footnotetext{
${ }^{1}$ Las reformas a las que se hace referencia son las siguientes: Ley 4/2013, de 4 de junio, de medidas de flexibilización y fomento del mercado del alquiler de viviendas; RD-ley 21/2018, de 14 de diciembre, de
} 
de 24 de noviembre, de Arrendamientos Urbanos (en adelante, LAU)-, en España el arrendamiento sigue sin ser una fórmula adecuada para satisfacer de modo permanente la necesidad de vivienda habitual, en particular de las familias, las cuales optan por el arrendamiento, bien de manera temporal, bien por la imposibilidad para acceder a la vivienda en propiedad.

Tal y como se ha puesto de relieve en distintos estudios y análisis, la situación no es la misma en todos los países de nuestro entorno. En particular, en Alemania el arrendamiento de viviendas no es, como en España, la opción a la que se acogen las familias solo durante cierto tiempo, generalmente hasta que se obtiene la financiación necesaria para la compra, sino que se presenta como una alternativa real a la adquisición en propiedad, de manera que no es excepcional, en el citado país, que las familias no sean nunca propietarias de la vivienda en la que habitan, incluso durante toda su vida, sino que sean, simplemente, arrendatarios de la misma.

Dada la deriva del mercado de vivienda en España, y las dificultades para acceder a la vivienda en propiedad por parte de muchas familias, resulta sumamente oportuno que desde las distintas disciplinas implicadas en el tema, que son muchas, se acometan estudios dirigidos a determinar las razones por las cuales el arrendamiento no es actualmente una alternativa idónea para satisfacer la necesidad de vivienda.

Este conocimiento resulta imprescindible para que el legislador pueda dar los pasos adecuados en lo referente a incrementar y mejorar las opciones de acceso a la vivienda. Y si de lo que se trata, entre otras cosas, es de conseguir que el arrendamiento sea en España una fórmula adecuada para el disfrute de la vivienda, tiene mucho sentido conocer las soluciones legislativas de aquellos ordenamientos jurídicos en los que esto ya ocurre.

De ahí la investigación que se acomete en estas páginas, cuyo objetivo no es otro que establecer, desde el conocimiento del Derecho alemán, propuestas de mejora y adecuación del Derecho arrendaticio español a la realidad socioeconómica actual. Es este el objetivo último del trabajo y no la mera comparación entre dos ordenamientos jurídicos. Pero el primer paso debe ser establecer las diferencias más destacadas entre el Derecho alemán y el español, no sin advertir que no se persigue, por supuesto, una exposición exhaustiva y detallada de las normas de uno y otro, no solo porque son prolijas sino, sobre todo, porque nos desviarían del objetivo anunciado.

medidas urgentes en materia de vivienda y alquiler (derogado por Acuerdo de 22 de enero de 2019); RDley $7 / 2019$, de 1 de marzo, de medidas urgentes en materia de vivienda y alquiler (convalidado por Acuerdo de 9 de abril de 2019). 
2. LOS DISTINTOS TIPOS DE ARRENDAMIENTOS DE VIVIENDA EN EL ORDENAMIENTO JURÍDICO ESPAÑOL. REFLEXIONES SOBRE SU ADECUACIÓN A LA REALIDAD ACTUAL

\subsection{Arrendamientos de vivienda en la legislación española}

En el presente apartado se expondrán los tipos de arrendamientos de vivienda existentes en la legislación española, las directrices y normas aplicables a cada uno de ellos y las razones que han llevado al legislador a establecer esta tipología. La expresión no se utiliza aquí en el sentido de la LAU vigente, sino como comprensiva, con carácter amplio, de todos los arrendamientos que tengan por objeto una vivienda.

Sin embargo, con carácter previo, cabe definir qué se entiende como "vivienda". La definición usual que del término establece la RAE es la siguiente: "lugar cerrado y cubierto construido para ser habitado por personas". En este artículo nos referiremos, por tanto, a los arrendamientos que recaigan sobre aquellos lugares cerrados y cubiertos que hubieran sido construidos para permitir que sean habitados por personas. Este concepto base de la vivienda deberá ser ampliado o reducido según el tipo de arrendamiento del que se trate, como veremos. La legislación añade requisitos para incluir o excluir del ámbito de aplicación de su régimen algunos tipos de vivienda que se corresponden con la definición usual, pero que no son aptos para el arrendamiento en las condiciones exigidas.

Actualmente, nuestra legislación diferencia entre tres tipos de arrendamiento que tienen por objeto una vivienda: el arrendamiento de la vivienda habitual, el arrendamiento de vivienda no habitual y el arrendamiento de una vivienda turística ${ }^{2}$. Se expondrá, respecto de cada uno de ellos, el concepto y su regulación, utilizando una metodología comparativa. Como se explicará, respecto de cada uno de los tres tipos, el primero se regula por la normativa proteccionista contenida en la legislación especial de arrendamientos urbanos, mientras que el segundo también pertenece al ámbito de aplicación de la LAU, pero se ubica entre los denominados "arrendamientos para uso distinto del de vivienda"3, con una regulación dispositiva y poco apropiada para este tipo,

\footnotetext{
${ }^{2}$ Para facilitar la exposición se han utilizado términos más descriptivos de los tres tipos de arrendamiento que recaen sobre una vivienda, no obstante, debe tenerse en cuenta que en la LAU se denominan, respectivamente, arrendamiento de vivienda, arrendamiento por temporadas $\mathrm{y}$, en cuanto a las viviendas turísticas, se describen, pero no se ofrece una terminología para ellos.

${ }^{3}$ En cuanto al concepto del arrendamiento para uso distinto del de vivienda, se recoge en el art. 3 LAU o, más bien, no se define, pues lo único que hace el precepto es usar la técnica de la definición por exclusión respecto del diferente destino al que debe quedar referido el arrendamiento que recaiga sobre la edificación. En concreto dice: "se considera arrendamiento para uso distinto del de vivienda aquel arrendamiento que, recayendo sobre una edificación, tenga como destino primordial uno distinto del establecido en el artículo anterior". A continuación, y en un intento de delimitar el concepto, se hace una enumeración de algunos supuestos que pertenecen a este tipo: "en especial, tendrán esta consideración los arrendamientos de fincas urbanas celebrados por temporada, sea esta de verano o cualquier otra, y los celebrados para ejercerse en la finca una actividad industrial, comercial, artesanal, profesional, recreativa, asistencial, cultural o docente, cualesquiera que sean las personas que los celebren". Dicho sea, ya que esta enumeración no cumple con el objetivo de delimitar debidamente el concepto, habida cuenta de que se trata de una enumeración abierta que, a mayor abundamiento, se refiere a supuestos que no comparten ninguna característica que justifique su tratamiento conjunto.
} 
por estar principalmente enfocada al arrendamiento de espacios destinados a finalidades empresariales; finalmente, los arrendamientos de viviendas turísticas han quedado excluidos de la LAU conforme a su art. 5, siempre y cuando se encuentren sometidos a la legislación sectorial turística dictada al efecto, en cuyo caso se regirán por lo dispuesto en el Código Civil (en adelante, CC). De no estar estos últimos arrendamientos sometidos a la normativa sectorial turística, sí se aplicaría al arrendamiento turístico en cuestión el régimen de la LAU, en concreto, el mismo que el de los arrendamientos de vivienda no habitual. Desarrollaremos estos aspectos a continuación.

Tal y como se puede intuir de lo expuesto, no todos los arrendamientos que recaen sobre una vivienda reciben la protección diseñada en el Título II LAU ${ }^{4}$. Muy por el contrario, se ubican conceptualmente entre los arrendamientos para uso distinto del de vivienda o bien directamente quedan excluidos del ámbito de aplicación de la LAU y, por ende, se rigen por lo dispuesto en el CC que contiene la normativa general de arrendamientos ${ }^{5}$, de carácter dispositivo ${ }^{6}$. Precisamente a la vista de esta circunstancia es fundamental delimitar el concepto de arrendamiento de vivienda que ofrece la LAU, por cuanto que de ello va a depender que, aun tratándose de una vivienda, resulte aplicable -o no- el régimen jurídico que señala el art. 4 LAU. En definitiva, actualmente, aun cuando el arrendamiento tenga por objeto una vivienda, dependiendo de otros factores que analizaremos a continuación, la regulación aplicable será, bien los pactos de las partes, dentro del marco del Título II LAU, bien los pactos de las partes y, solo en su defecto, el Título III LAU, en ambos casos con aplicación supletoria del Código Civil, o bien, directamente quedarán sujetos a la normativa general del Código Civil.

\subsection{A. Arrendamiento de vivienda habitual o de necesidad permanente de vivienda}

El legislador español, al establecer el régimen especial de los arrendamientos de vivienda, en la LAU, no se refiere a todos los arrendamientos que pueden recaer sobre la vivienda entendida como "lugar cerrado y cubierto construido para ser habitado por personas", sino que se refiere a un supuesto muy concreto, que es el arrendamiento de la vivienda habitual. Ciertamente, no se expresa con esa terminología, pero de los requisitos señalados en la LAU para considerar aplicable la normativa especial se puede extraer esa conclusión. Buena prueba de ello es, entre otros, el art. 7 LAU que aclara que, aun a pesar

\footnotetext{
${ }^{4}$ La estructura de la vigente LAU se compone de cinco títulos, si bien el V está derogado. El I regula el "ámbito de la ley" (arts. 1-5); el II "De los arrendamientos de vivienda", dividido en cinco capítulos (arts. 6-28); Título III "De los arrendamientos para uso distinto de vivienda" (arts. 29-35), IV "Disposiciones comunes" (arts. 36 y 37), y el derogado Título V "Procesos arrendaticios" (arts. 38-40). Finalmente, diez disposiciones adicionales, seis disposiciones transitorias, una única disposición derogatoria y cuatro disposiciones finales.

${ }^{5} \mathrm{El}$ arrendamiento de cosas se regula en los arts. 1542 a $1582 \mathrm{CC}$.

${ }^{6}$ En palabras de LACRUZ BERDEJO, J.L., Estudios de Derecho Privado común y foral. Tomo II, Barcelona, Bosch, 2005, pág. 3: "Tanto el proyecto de CC del 1851, como el CC vigente, 1889, regulan los arrendamientos urbanos en un sentido de respeto absoluto -acaso excesivo-a la posición del propietario, y de completa libertad contractual: ni en materia de plazos y rentas, ni en cualquier otra, se hallan preceptos imperativos".
} 
de que el arrendatario no resida en la vivienda arrendada, el arrendamiento sigue quedando sometido a la normativa proteccionista de la LAU, siempre y cuando el cónyuge no separado legalmente o de hecho o los hijos dependientes del arrendatario habiten permanentemente en la vivienda. En concreto, la definición que ofrece el art. 2 LAU es la siguiente: "aquel arrendamiento que recae sobre una edificación habitable cuyo destino primordial sea satisfacer la necesidad permanente de vivienda del arrendatario", o de su cónyuge no separado legalmente o de hecho o sus hijos dependientes, como ya se ha adelantado.

A la vista del contenido del art. 2, se puede conceptuar el arrendamiento de vivienda siguiendo dos criterios diferenciados; de un lado, el objeto sobre el que debe recaer, esto es, una "edificación habitable"7 y el destino primordial "satisfacer la necesidad permanente de vivienda". Esta dualidad tendrá especial relevancia para incluir o excluir de la regulación de la LAU determinados arrendamientos que recaen sobre una vivienda, sobre todo, como veremos, en la jurisprudencia, puesto que si bien pudiera pensarse que para apreciar que existe arrendamiento de vivienda deben concurrir los dos elementos (edificación habitable y destino), también lo es que algunos arrendamientos que recaen sobre viviendas se han excluido por la jurisprudencia de la aplicación de la LAU por dar mayor relevancia a alguno de los dos elementos (por ejemplo, a la habitabilidad de la edificación, con independencia del destino). Y ello teniendo en cuenta que la doctrina coincide en que cada uno de los elementos resulta insuficiente sin el otro para configurar el concepto del arrendamiento de vivienda ${ }^{8}$.

Empezando con el primero de los elementos, esto es, la habitabilidad de la edificación, la doctrina y la jurisprudencia coinciden en que no se trata del cumplimiento de los requisitos administrativos o de la concurrencia, respecto de la edificación de la que se trate, de la cédula de habitabilidad ${ }^{9}$. Sí se exige, tanto por doctrina como jurisprudencia,

\footnotetext{
${ }^{7}$ Además de los requisitos señalados en el art. 2 LAU, parece que debiera completarse con lo dispuesto en el art. 1 del mismo cuerpo legal, pues limita el ámbito de aplicación de la ley a los arrendamientos que tengan por objeto una finca urbana, eso sí, sin definir qué debe entenderse por tal. Sin embargo, la doctrina prácticamente de forma unánime, considera que la "finca urbana" a que se refiere el artículo debe diferenciarse de las fincas rústicas a las que resultará de aplicación la Ley 49/2003, de 26 de noviembre, de Arrendamientos Rústicos, y que no cabe sino identificarla con una edificación, pues tanto el art. 2, para los arrendamientos de vivienda, como el art. 3, para los arrendamientos para uso distinto de vivienda se refieren no ya a una finca urbana, sino a una edificación, con la única diferencia de que el primero añade el requisito de la habitabilidad y el segundo no. Se manifiesta en este sentido GUILARTE GUTIÉRREZ, V., "Artículo 2. Arrendamiento de vivienda", en Comentarios a la Ley de Arrendamientos Urbanos, (dirs. Crespo Allué, F. y Guilarte Gutiérrez, V.), Valladolid, Thomson Reuters, 1ª ed., 2014, pág. 34, criticando que "el hecho de que el legislador se refiere en el artículo 1 a la finca urbana y en los artículos 2 y 3 se exija la existencia de una edificación hace que no tengan cobijo alguno en la ley las fincas urbanas no edificadas por lo que la persistencia de aquel concepto -finca urbana- en el artículo 1 no tiene sentido ni finalidad alguna, limitándose a introducir un cierto confusionismo en la exégesis de estos preceptos". También proclaman la identidad entre finca urbana y edificación VALLADARES RASCÓN, E. y ORDÁS ALONSO, M., "Artículo 1. Ámbito de aplicación", en Comentarios a la Ley de Arrendamientos Urbanos, (coord. Bercovitz Rodríguez-Cano, R.), Cizur Menor, Aranzadi, 7. ed., 2020, pág. 77.
}

${ }^{8}$ GUILARTE GUTIÉRREZ, V., "Artículo 2. Arrendamiento de vivienda”, op. cit., pág. 30.

${ }^{9}$ VALLADARES RASCÓN, E. y ORDÁS ALONSO, M., "Artículo 2.1. Arrendamiento de vivienda", en Comentarios a la Ley de Arrendamientos Urbanos, (coord. Bercovitz Rodríguez-Cano, R.), Cizur Menor, 
que la edificación reúna las condiciones que, de forma objetiva, sean necesarias para que el arrendatario -y su familia- puedan realizar las actividades propias del ámbito doméstico. A ello se añade también la necesidad de que puedan desarrollar dichas actividades en un espacio respetuoso con la intimidad familiar ${ }^{10}$.

Complemento del requisito anterior es el destino que se dé a la edificación habitable arrendada y que debe consistir en la satisfacción de la necesidad permanente de vivienda del arrendatario, que no queda excluida cuando no sea el arrendatario el que habite la vivienda, siempre y cuando su cónyuge, no separado legalmente o de hecho, o su hijo dependiente residan en la vivienda arrendada. La doctrina critica el adjetivo que utiliza la LAU para definir el destino que deba darse a la necesidad de vivienda del arrendatario. Entendiendo, con GUILARTE GUTIÉRREZ11 que el término "primaria" que, en sede parlamentaria, se propuso junto al de "permanente" hubiera sido más adecuado, para evitar toda confusión en cuanto a si el carácter permanente se refiere a la necesidad o sirve para delimitar la duración del contrato (teniendo en cuenta que del propio concepto de arrendamiento se deriva su temporalidad ${ }^{12}$. En concreto, explica el citado autor que la necesidad permanente de vivienda se puede delimitar en el sentido de que "todo individuo, siempre (permanentemente), tiene la necesidad de residir en algún lugar, y esa perpetua necesidad es la que la ley tutela cuando se atiende a través del contrato de alquiler".

Cuando se destine la vivienda arrendada a satisfacer la necesidad permanente del arrendatario, esto es, cuando deba servir como vivienda habitual del arrendatario, el régimen aplicable al mismo, según el art. 4 LAU, será eminentemente imperativo, pero con matices: en principio, arrendador y arrendatario podrán establecer los pactos que estimen oportunos, siempre y cuando sean conformes con los dictados del Título I, II y IV de la LAU. El propio art. 4 declara imperativos los artículos contenidos en el Título I, así como los dos artículos que contiene el Título IV y que se refieren, respectivamente, a la fianza y garantías adicionales y a la formalización del contrato (cfr. arts. 36 y 37 LAU). Asimismo, respecto de las normas del Título II aclara que los contratantes no podrán apartarse de la letra de la ley en perjuicio del arrendatario, salvo que la propia norma así lo establezca (art. 6) y que, en todo caso, la exclusión deberá constar expresamente (art. 4.4). Para todo aquello no pactado por las partes, ni recogido en la legislación especial, se aplica supletoriamente la norma general, el Código Civil.

Aranzadi, 7. a ed., 2020, pág. 81; GUILARTE GUTIÉRREZ, V., "Artículo 2. Arrendamiento de vivienda", op. cit., pág. 36 .

${ }^{10}$ GUILARTE GUTIÉRREZ, V., “Artículo 2. Arrendamiento de vivienda”, op. cit., págs. 35-36.

${ }^{11}$ GUILARTE GUTIÉRREZ, V., "Artículo 2. Arrendamiento de vivienda”, op. cit., pág. 41.

${ }^{12}$ De hecho, tal y como explican VALLADARES RASCÓN, E. y ORDÁS ALONSO, M., "Artículo 2.1. Arrendamiento de vivienda", op.cit., pág. 101: "el arrendatario no puede, por definición, tener su vivienda permanente en la finca arrendada, pues deberá abandonarla al concluir el plazo pactado $\mathrm{y}$, en su caso, las prórrogas". 
A la vista del régimen jurídico expuesto en el art. 4 LAU cabe plantearse qué motivos tuvo el legislador para limitar la autonomía de la voluntad de las partes respecto de los arrendamientos regulados por el CC. Los antecedentes normativos de la legislación especial muestran que desde la primera ley especial locaticia posterior al $\mathrm{CC}^{13}$, esto es, el Decreto de 21 de junio de 1920, la preocupación del legislador era la de combatir los efectos de la escasez de la vivienda y el abuso de los propietarios que, aprovechando esta situación, elevaban las rentas de las viviendas arrendadas a sabiendas de la dificultad del arrendatario para buscar otra ${ }^{14}$. La autonomía de la voluntad que en sede arrendaticia regía por virtud del régimen común del $\mathrm{CC}$, hacía posible este tipo de abusos por parte de los propietarios y necesaria una intervención por parte del legislador para regular los intereses en juego. Para evitar estos abusos, el legislador español optó por dictar normas especiales que, respecto de algunos arrendamientos urbanos, limitara la autonomía propia del CC. La continua publicación de modificaciones y de nuevas leyes especiales en el ámbito de los arrendamientos urbanos tenía como justificación, según las distintas exposiciones de motivos, la ausencia de los resultados proyectados en las mismas. Ya fuera, de un lado, por la falta de cumplimiento de las medidas complementarias apuntadas por el legislador (incremento de la inversión privada y pública, aumento de la construcción y rehabilitación de viviendas), y de otra, por la inadecuación de las normas dictadas.

La imperatividad de la legislación especial se centra en el establecimiento de una duración mínima e inderogable para las partes, pues es obligatoria para el arrendador e irrenunciable con carácter previo para el arrendatario. La duración mínima comprende actualmente cinco años (o siete, en caso de que el arrendador fuera una persona jurídica), que se alcanzan por medio de un sistema de prórrogas anuales y es en el vencimiento de cada una de estas prórrogas en los que entra en juego la voluntariedad para el arrendatario, pues podrá notificar su voluntad de no continuar arrendando la vivienda treinta días antes de cada vencimiento anual. No obstante lo anterior, no debe confundirse la prórroga obligatoria con la determinación inicial de la duración del arrendamiento, que podrá ser libremente determinada por las partes. La intervención legislativa respecto de la duración consiste en establecer un plazo mínimo durante el cual el arrendatario no podrá ser desalojado de la vivienda, precisamente por tratarse de su vivienda habitual. Por ello, con independencia de que las partes pacten una duración para el contrato, si esta fuera inferior a los cinco años a los que se refiere la norma, se aplicarán las prórrogas anuales de forma obligatoria para el arrendador y voluntaria para el arrendatario. Este sistema de prórrogas

13 Con anterioridad a la promulgación del CC, el legislador ya se había ocupado de regular los arrendamientos urbanos, por ejemplo, en la Ley de 9 de abril de 1842 que consagraba el principio de la autonomía de la voluntad en sede arrendaticia y la extinción del arrendamiento una vez cumplido el término pactado, sin que fuera necesario que el propietario ejercitara la acción de desahucio. ARAGONESES ALONSO, P. y PASCUAL NIETO, G., "La vigente ley de arrendamientos y nuestro Derecho Histórico", Anuario de Derecho Civil, vol.9, núm. 1, 1956, pág. 51, explican que esta ley surge por la presión de los propietarios que reclamaban la instauración de la libertad contractual en la regulación de los arrendamientos urbanos, como respuesta a las normas proteccionistas que venían publicándose hasta la fecha. Los principios inspiradores de esta ley encontrarían su reflejo en la regulación del CC.

${ }^{14}$ En la Exposición de Motivos del Decreto de 21 de junio de 1920 se exponía este problema "es evidente que la escasez de habitaciones viene colocando al inquilino en situación de verdadera angustia, de la que algún propietario ha podido prevalerse para aumentar de modo exorbitante el importe de los arriendos". 
se recoge principalmente en los arts. 9 y $10 \mathrm{LAU}$, si bien inspira prácticamente la totalidad de las normas que regulan el arrendamiento de la vivienda habitual. El legislador entiende, actualmente, que la duración de cinco años es protección suficiente para el arrendatario, y a su vez, que no desincentiva en demasía a los arrendadores para ofrecer en arrendamiento sus inmuebles. Complementa esta primera prórroga obligatoria con otra prórroga anual más breve, hasta los tres años, con la importante diferencia de que el arrendador puede evitarla notificándoselo al arrendatario con anterioridad al comienzo de la primera anualidad. Una vez que se inicie el sistema de prórroga del art. 10 LAU, su acatamiento vuelve a ser obligatorio para el arrendador y voluntario para el arrendatario.

Siendo el sistema de prórrogas el aspecto principal sobre el que gira toda la regulación del arrendamiento de vivienda habitual, se puede decir que se trata de una regulación completa para este tipo de arrendamiento, pues regula tanto los derechos y obligaciones de arrendador y arrendatario, y las consecuencias del incumplimiento de los mismos, como aquellos actos o hechos que puedan amenazar al sistema de prórrogas, estableciendo distintas soluciones para cada supuesto. En este sentido, se prevén soluciones para los supuestos de que un tercero adquiera la vivienda arrendada, ya sea por medio de la enajenación voluntaria de la misma (art. 14) o forzosa (art. 13), o porque el tercero ejercite un derecho que tenga por consecuencia la resolución del derecho del arrendador.

Asimismo, a la vista de que, como se ha adelantado, se regula el arrendamiento de la vivienda habitual, el legislador ha tenido en consideración a los familiares del arrendatario y ha extendido la protección prevista para aquel a estos. Se regula, entre otros, la subrogación en el contrato de algunos familiares del arrendatario en caso de que este fallezca (art. 16). Respecto del núcleo familiar, se prevé también la subrogación del cónyuge no arrendatario en la posición de este, en caso de que desista o abandone la vivienda sin consentimiento del cónyuge (art. 12), además de las consecuencias de una crisis matrimonial en cuanto a la continuidad en la vivienda del cónyuge no arrendatario (art. 15).

En definitiva, se caracteriza el régimen jurídico del arrendamiento de vivienda habitual por ser un sistema proteccionista, imperativo y completo. No obstante, se puede apreciar, dentro de la regulación pendular propia en materia de arrendamiento de vivienda habitual, que el grado de protección actual, en una perspectiva histórica, no es demasiado elevado. En palabras de AVILÉS GARCÍA “esta fluctuación legal en materia de protección del inquilino ha sido periódica y constante: de la hiperprotección legislativa del inquilino anterior al Texto refundido de 1964 se pasó a cierta laxitud en la tutela del inquilino, y de ésta a la liberalización por Real Decreto-Ley 2/1985, con retorno, pocos años después, a una protección guiada bajo el principio del equilibrio prestacional entre contratantes por Ley 29/1994, sin apenas conseguir incrementar el mercado de alquiler"15.

\footnotetext{
${ }^{15}$ AVILÉS GARCÍA, J., "Política de acceso a la vivienda, arrendamiento vigilado y libertad de mercado en la nueva LAU", Revista de Derecho Patrimonial, núm. 34/2014, pág. 53.
} 
2.1.B. Arrendamiento de vivienda no habitual o de necesidad transitoria de vivienda

Bajo esta terminología se hace referencia a los arrendamientos que, aun recayendo sobre una vivienda, no responden a una necesidad permanente de vivienda, sino a una necesidad transitoria. La doctrina, con algún apoyo legal, los llama "arrendamientos de temporada".

Dado que las primeras leyes especiales no regulaban el arrendamiento de temporada, limitándose a mencionarlo a los efectos de su exclusión del ámbito de aplicación, no se ha concretado su concepto, si bien pueden extraerse los elementos que lo caracterizan y permiten calificarlo como tal de sus antecedentes legislativos y de la jurisprudencia. El art. 3 en sus apartados $1^{\circ}$ y $2^{\circ}$ LAU establece como requisitos los siguientes: 1) que el arrendamiento recaiga sobre una edificación (si bien el apartado $2^{\circ}$ se refiere a la finca urbana, en el apartado $1^{\circ}$ se hace referencia a la edificación); y 2) que el destino primordial del arrendamiento sea distinto al de satisfacer la necesidad permanente de vivienda del arrendatario. La jurisprudencia consolidada del Tribunal Supremo establece que el contrato de arrendamiento se califica como celebrado por temporadas en función de la finalidad que subyace al arrendamiento, sin que sea determinante la duración pactada para el contrato, ni lo que hubieran establecido las partes en el contrato. En este sentido, cabe citar, por todas, la STS, Sala $1^{\text {a }}$., de 15 de diciembre de $1999^{16}$ (ROJ: STS 8059/1999), que con cita de la STS anterior de 19 de febrero de 1982, y de la jurisprudencia constante que ha mantenido al respecto, aclara que: "debiendo entenderse este requisito de 'temporalidad' de un modo amplio y flexible cuando claramente se infiera que el uso y ocupación de que el inmueble es objeto responda a exigencias circunstanciales, esporádicas o accidentales determinantes del contrato y elevadas expresamente a la condición de causa por las partes, como sucede en el presente caso, y no a la necesidad de habitar permanentemente o de la adecuada instalación del negocio o industria del ininterrumpido desenvolvimiento, ya que el requisito de la temporalidad de la ocupación guarda relación, no con el plazo de duración simplemente cronológico, sino con la finalidad a que va encaminado el arrendamiento determinante de su ocupación, y así lo tiene declarado la doctrina jurisprudencial de esta Sala en ss. 17 dic. 1960, 8 feb. 1962, 30 mar. 1974, 4 feb. 1975 y 30 jun. 1976”.

Una vez delimitados los requisitos que permiten calificar el arrendamiento, cabe plantearse las razones que han llevado al legislador a subsumir este tipo de arrendamiento dentro de la categoría de los arrendamientos para uso distinto del de vivienda y al régimen jurídico establecido en la LAU para estos. Sobre todo, a la vista de que, históricamente, este tipo de arrendamiento ha sido excluido de la normativa especial por el legislador ${ }^{17}$,

\footnotetext{
${ }^{16}$ ECLI:ES:TS:1999:8059.

${ }^{17}$ Disponía el art. 2 de la Ley de 31 de diciembre de 1946 (articulada por la Orden de 21 de marzo de 1947) "Quedan excluidos de la presente Ley y se regirán por lo pactado y por lo establecido con carácter necesario en el Código Civil o en la Legislación foral, en su caso, y en las Leyes procesales comunes, los arrendamientos, cesiones y subarriendos de viviendas o locales de negocio, con o sin muebles, de fincas situadas en lugares en que el arrendatario no tenga su residencia habitual y limitados a la temporada de verano o a cualquier otra”. Similar contenido tenía el precepto 1.2. $1^{\circ}$ de la Ley de 22 de diciembre de 1955 (articulada por el Decreto de 13 de abril de 1956), con una mínima variación, eliminando la referencia a la
} 
optando, en cambio, por una dualidad: el arrendamiento de vivienda permanente y el arrendamiento de locales de negocios ${ }^{18}$. Se justificaba la exclusión por el legislador, según el Preámbulo de la Ley de Bases de 31 de diciembre de 1946 (primera ley especial que se refería a los arrendamientos de temporada) "por no venir [los arrendamientos de temporada] generalmente impuestos por la necesidad de residencia, sino por otras finalidades distintas y complejas, no hay razón para cohibir la libre voluntad de las partes en su otorgamiento". Si bien el tipo del arrendamiento de vivienda ha permanecido inalterado, salvo por la delimitación de su contenido, ya sea en función de las personas que habiten en la vivienda, o del tamaño de la misma o de la renta (las llamadas viviendas suntuarias ${ }^{19}$ para las que establece el mismo régimen que el de los arrendamientos para uso distinto de vivienda); el del arrendamiento de local de negocio se ha sustituido por el difícil por indefinido tipo del arrendamiento "para uso distinto de vivienda". Se delimita, principalmente, por exclusión: todo destino que no concuerde con la satisfacción de la necesidad permanente de vivienda, pero que recaiga sobre una edificación, tendrá cabida en este segundo tipo ${ }^{20}$. A salvo quedan los supuestos señalados en el art. 5 LAU, que directamente, por elección del legislador, quedan excluidos de la aplicación de la LAU, a veces, con una difícil justificación y con una deficiente técnica jurídica.

A partir de la LAU de 1994, se incluye, por primera vez, el arrendamiento de vivienda no habitual en su ámbito de aplicación, sin embargo, no se adapta la normativa, en el sentido de eliminar la dualidad propia de las leyes anteriores, estableciendo normas adecuadas para este tercer tipo, sino que, manteniendo la idea de que no puede ser considerado

residencia habitual y añadiendo la aclaración "aunque los plazos concertados para el arrendamiento fueran distintos". En similares términos se pronunciaba el art. 2.1 del Decreto 4104/1964, de 24 de diciembre, por el que se aprueba el Texto Refundido de la Ley de Arrendamientos Urbanos 1964 (en adelante, TRLAU): "Quedan excluidos y se regirán por lo pactado y por lo establecido con carácter necesario en el Código Civil o en la legislación foral, en su caso, y en las Leyes procesales comunes, los arrendamientos, cesiones y subarriendos de viviendas o locales de negocio, con o sin muebles, de fincas cuyo arrendatario las ocupe únicamente por la temporada de verano, o cualquier otra, aunque los plazos concertados para el arrendamiento fueran distintos".

18 Tanto la Ley de 31 de diciembre de 1946, como la Ley de Bases de 22 de diciembre de 1955 (articulada por el Decreto de 13 de abril de 1956), hasta el TRLAU de 1964 diferenciaban entre el arrendamiento de viviendas o inquilinato y el arrendamiento de local de negocio.

${ }^{19}$ Fue la Ley de 22 de diciembre de 1955 (articulada por Decreto de 13 de abril de 1956) la que indicó, por primera vez, que los derechos indicados en la misma son renunciables, excepto el de la prórroga, para aquellos arrendatarios que ocupen por primera vez una vivienda que devengue ciertas cantidades mensuales que se indican por franjas en una tabla. En similares términos, el TRLAU de 1964, en su art. 6.2 declara renunciables los derechos concedidos, salvo el de prórroga, para viviendas que devengan las cantidades indicadas en las escalas por fecha y cuantía. Por su parte, la LAU de 1994, tanto en su redacción original como en la actualmente vigente (redacción dada por el RD-ley 7/2019) regulan en su art. 4.2 la excepción a la regulación de las viviendas suntuarias (cuya superficie sea superior a 300 metros cuadrados o en los que la renta inicial en cómputo anual exceda de 5,5 veces el salario mínimo interprofesional en cómputo anual), a las que resultarán de aplicación los pactos, en su defecto el Título II, y supletoriamente el CC.

${ }^{20}$ A la vista de la imprecisa tipología actual, al menos en las leyes anteriores el arrendamiento de local de negocio estaba mejor delimitado, pues si bien se decía, tanto en la Ley de bases de 31 de diciembre de 1946 (base primera) y en el TRLAU de 1964 que eran contratos de arriendo que recaían sobre aquellas otras edificaciones habitables cuyo destino primordial no fuera la vivienda, aclaraba a continuación que dicho destino fuera, en cambio, el de ejercerse en ellas, con establecimiento abierto, una actividad de industria, de comercio o de enseñanzas con fin lucrativo. 
arrendamiento de vivienda permanente y, por ende, no siendo merecedor de la protección que se establece para aquel ${ }^{21}$, se incluye en la categoría del arrendamiento para uso distinto de vivienda, heredero de la que antaño fuera la categoría del arrendamiento del local de negocio.

Llama la atención la decisión del legislador cuando, como se ha dicho, la sujeción del arrendamiento de temporada al régimen del arrendamiento para uso distinto del de vivienda no tiene ninguna justificación ${ }^{22}$. Dado que el régimen de arrendamientos contenido en el CC es eminentemente dispositivo, y que se trata de la norma general, aplicable a los arrendamientos que no entren en el ámbito de aplicación de la LAU (y de forma supletoria a los que sí entren en su ámbito de aplicación), hasta la promulgación de la LAU de 1994, el arrendamiento por temporadas quedaba sujeto al CC ${ }^{23}$. La autonomía de la voluntad de las partes era la característica principal de su régimen. Se ha mantenido ${ }^{24}$ que la razón que subyace a la decisión del legislador es la de modernizar la regulación aplicable a algunos arrendamientos urbanos, puesto que la normativa del $\mathrm{CC}$ resultaba obsoleta en demasiados aspectos (lógico, por otra parte, habida cuenta de la fecha en la que se dictó esta normativa de arrendamientos que ha llegado inalterada hasta la actualidad), sin pretender, en cambio, limitar en demasía la libertad de las partes al aplicar el régimen de los arrendamientos de vivienda habitual.

A partir de la LAU 1994, por tanto, y como consecuencia de su inclusión en el art. 3 LAU, le será de aplicación el régimen jurídico propio de los arrendamientos para uso distinto del de vivienda. Un régimen que, a diferencia de lo dispuesto para los arrendamientos de la vivienda habitual, se caracteriza por ser de carácter dispositivo. Así, excepto lo dispuesto en los Títulos I y IV, que son de carácter imperativo, se podrán establecer los pactos que se consideren oportunos $\mathrm{y}$, solo en defecto de pacto, tendrá aplicación lo dispuesto en el Título III, con la supletoriedad del CC. Una aclaración importante que introduce el apartado $4^{\circ}$ del art. 4 LAU es que cualquier exclusión de las normas deberá hacerse de forma expresa, siendo esta una norma que tendrá carácter imperativo tanto

\footnotetext{
${ }^{21}$ De hecho, exactamente así lo dice el legislador en la Exposición de Motivos de la LAU "Este nuevo categorismo se asienta en la idea de conceder medidas de protección al arrendatario sólo allí donde la finalidad del arrendamiento sea la satisfacción de la necesidad de vivienda del individuo y de su familia, pero no en otros supuestos en los que se satisfagan necesidades económicas, recreativas o administrativas".

${ }^{22}$ Tanto es así, que el legislador ni siquiera ha tratado de justificar en la Exposición de Motivos la razón de incluir el arrendamiento de temporada entre los arrendamientos para uso distinto de vivienda, y ello a pesar del precedente legislativo en el que se excluía de las leyes arrendaticias especiales el arrendamiento de temporada.

${ }^{23}$ De hecho, las leyes anteriores indicaban expresamente que estos arrendamientos quedarían sometidos a la voluntad de las partes y al régimen común.

${ }^{24}$ En palabras de MORENO-TORRES HERRERA, M.L. y MARTENS JIMÉNEZ, I.L., "Pasado, presente y futuro de la regulación de los arrendamientos de viviendas turísticas en el ordenamiento español", Revista Jurídica del Notariado, núm. 112, 2021, pág. 278: “Así pues, la técnica de la ley especial, que se utiliza en un primer momento para introducir restricciones a la autonomía privada con la finalidad de proteger a los arrendatarios, se emplea ahora con un fin distinto: modernizar el derecho arrendaticio. El Derecho codificado no resultaba inútil, pero sí insuficiente ante la evolución socio-económica acaecida en el último siglo".
} 
para los arrendamientos de vivienda como para los de uso distinto. El significado de esta norma se concreta en la imposibilidad de realizar una exclusión en bloque de las normas contenidas en el Título III LAU ${ }^{25}$. En efecto, dice el art. 4.4 que la exclusión "deberá hacerse de forma expresa respecto de cada uno de ellos [los preceptos de la ley]" y, conforme al art. 4.1, también para el arrendamiento para uso distinto tiene carácter imperativo "lo dispuesto en los apartados siguientes de este artículo".

Además, se caracteriza por ser un régimen incompleto y una normativa inadecuada, al estar claramente orientada a regular situaciones concretas propias de los arrendamientos que recaen sobre locales o viviendas en las que se ejerza una actividad profesional o económica. Buena prueba de ello son normas tales como la recogida en el art. 34 que se refiere a la indemnización que corresponde al arrendatario que a pesar de su voluntad de renovar el contrato por un mínimo de cinco años más, debe abandonar el local en el que ha ejercitado su actividad comercial de venta al público por igual periodo de tiempo. Esta norma, si bien es dispositiva, es una de las siete normas que contiene el Título III de la LAU. También se refieren expresamente a la actividad empresarial o profesional, el art. 32 (cesión y subarriendo de la finca arrendada en la que se ejerza una actividad empresarial o profesional), el art. 33 (muerte del arrendatario cuando en el local se ejerza una actividad empresarial o profesional) y el 35 (resolución de pleno derecho, aparte de determinadas causas enumeradas del art. 27, nombra expresamente la cesión o subarriendo del local en incumplimiento de lo dispuesto en el art. 32). Nótese que de siete artículos que contiene el Título III de la LAU (regulación aplicable a los arrendamientos para uso distinto, en defecto de pacto), cuatro se refieren expresamente a un local en el que se ejerza una actividad empresarial o profesional. Es evidente, por ende, que este Título III no está diseñado, en absoluto, para regular el arrendamiento de temporada. No resuelve ninguno de los aspectos del contenido contractual del arrendamiento de temporada, sino, como se ha dicho, lo contrario, aspectos propios y apropiados para un local comercial. A mayor abundamiento, si el arrendamiento de temporada es considerado un arrendamiento para uso distinto, significa que el Título I y el Título IV tienen carácter imperativo para estos contratos, consecuentemente, cualquiera de los contratantes podrá compeler al otro para celebrar el contrato en forma escrita y el arrendatario quedará obligado al pago de hasta dos meses de fianza, sin perjuicio de las posibles garantías adicionales. Especialmente inadecuada puede resultar esta norma para arrendamientos de temporada muy cortos (piénsese en la temporada de verano, que abarcaría tres meses), pues la fianza alcanzaría prácticamente a la totalidad de la renta pactada.

En definitiva, el régimen jurídico del arrendamiento de necesidad transitoria de vivienda se caracteriza por ser un sistema no proteccionista, dispositivo, incompleto e inadecuado, al ser una normativa orientada a locales, y de mínimos. Alcanzada esta conclusión, no es baladí preguntarse si el Código civil ofrece respuestas adecuadas al llamado arrendamiento de temporada. Pudiera pensarse que sí, sobre todo a la vista de los

${ }^{25}$ En este sentido, BERCOVITZ RODRÍGUEZ-CANO, R., "Artículo 4.3. Régimen aplicable", en Comentarios a la Ley de Arrendamientos Urbanos, (coord. Bercovitz Rodríguez-Cano, R.), Cizur Menor, Aranzadi, 7. ${ }^{a}$ ed., 2020, pág. 151. 
precedentes históricos: todas las leyes especiales anteriores a la LAU excluían expresamente el arrendamiento por temporadas de su ámbito de aplicación, por lo que debía entenderse aplicable la norma general. No obstante, como veremos, no es así.

\subsection{Arrendamiento de vivienda turística}

El arrendamiento de viviendas turísticas o arrendamiento turístico, al amparo de lo establecido en el art. 5 e) LAU, es aquel contrato por virtud del cual una persona cede a otra, a cambio de un precio, el uso, por un tiempo determinado, de una vivienda, amueblada y perfectamente equipada y en condiciones de uso inmediato, y destinada a cubrir una necesidad transitoria.

El arrendamiento de viviendas turísticas no siempre se ha considerado como un tipo independiente, sino que se recogía dentro de los arrendamientos por temporada. No es hasta el año $2013^{26}$ cuando se diferencia entre ambos tipos de arrendamiento, de tal manera que, como ya ha quedado expuesto, el arrendamiento por temporada o el arrendamiento transitorio de vivienda, se regula dentro de la categoría de los arrendamientos para uso distinto del de vivienda, con el régimen ya expuesto, mientras que el arrendamiento de viviendas turísticas ha sido extraído del ámbito de aplicación de la LAU, siempre que reúna los requisitos que enumera el art. 5.

La justificación para añadir el apartado e) al art. 5 LAU era, según el Preámbulo de la Ley 4/2013, que "en los últimos años se viene produciendo un aumento cada vez más significativo del uso del alojamiento privado para el turismo, que podría estar dando cobertura a situaciones de intrusismo y competencia desleal, que van en contra de la calidad de los destinos turísticos; de ahí que la reforma de la Ley propuesta los excluya específicamente para que queden regulados por la normativa sectorial específica o, en su defecto, se les aplique el régimen de los arrendamientos de temporada, que no sufre modificación".

En efecto, el apartado e) del art. 5 LAU, conforme a la redacción dada por el RD-ley 7/2019, establece que: "Quedan excluidos del ámbito de aplicación de esta ley: e) La cesión temporal de uso de la totalidad de una vivienda amueblada y equipada en condiciones de uso inmediato, comercializada o promocionada en canales de oferta turística o por cualquier otro modo de comercialización o promoción, y realizada con finalidad lucrativa, cuando esté sometida a un régimen específico, derivado de su normativa sectorial turística".

El principal inconveniente que deriva del precepto citado es que lleva a una consecuencia -quizás no querida por el legislador- y es que se genera una dualidad de regímenes para los arrendamientos turísticos: de un lado, aquellos arrendamientos que consisten en la

\footnotetext{
${ }^{26}$ La redacción original del apartado e) conforme a la Ley 4/2013 excluía del ámbito de aplicación de la LAU "la cesión temporal de uso de la totalidad de una vivienda amueblada y equipada en condiciones de uso inmediato, comercializada o promocionada en canales de oferta turística y realizada con finalidad lucrativa, cuando esté sometida a un régimen específico, derivado de su normativa sectorial”.
} 
cesión temporal de uso de la totalidad de una vivienda amueblada y equipada en condiciones de uso inmediato, comercializados y con finalidad lucrativa que no estén sometidos a un régimen específico, derivado de su normativa sectorial turística, que quedan sometidos a la LAU por pertenecer como subtipo a los arrendamientos de vivienda no habitual; y, aquellos otros que sí cuenten con un régimen específico, derivado de su normativa sectorial turística, que quedarán sometidos, en cuanto al contenido obligacional del contrato, al régimen común contenido en el $\mathrm{CC}$, sin perjuicio de las normas de Derecho público que, sobre los requisitos de la vivienda a arrendar y el control de la actividad turística, se establecen en la normativa sectorial ${ }^{27}$.

En este sentido es sumamente importante aclarar que la referencia que hace el art. 5.e) LAU al "régimen específico, derivado de su normativa sectorial turística" no se refiere a la regulación del contenido del arrendamiento, sino al objeto del mismo, en concreto, a la actividad de explotación de las viviendas destinadas a fines turísticos. En efecto, mientras que las comunidades autónomas tienen competencia para regular el sector del turismo (art. 148.18 $\mathrm{CE}$ ) y, por ende, establecer las normas oportunas de Derecho público, es el legislador estatal el que tiene competencia para regular los arrendamientos urbanos (art. 149.1.8 $\mathrm{CE}$ ), por lo que, de no quedar sujeto el arrendamiento turístico a la LAU, le será de aplicación la normativa general de arrendamientos urbanos contenida en el CC.

Se llega, por tanto, a un estado de cosas en el que los arrendamientos turísticos, dependiendo de si están sujetos o no a la normativa sectorial turística de la comunidad autónoma, quedan sometidos bien, en defecto de pacto, al régimen común del $\mathrm{CC}$, o bien, nuevamente en defecto de pacto, al Título III LAU (y también al Título I y IV, con carácter imperativo), siendo el CC de aplicación supletoria.

En cualquier caso, ninguno de los dos posibles regímenes aplicables al arrendamiento de vivienda turística es adecuado para responder a las particularidades propias de este tipo de arrendamiento, pues el Título III LAU contiene normas específicamente pensadas para resolver cuestiones relacionadas con un arrendamiento de espacios dedicados a actividades empresariales, y el CC, al regular el arrendamiento de cosas y, dentro de este, el arrendamiento urbano, buscando la generalidad y la posibilidad de atender a todos los posibles objetos sobre los que puede recaer el arrendamiento, no logra, precisamente por virtud de esa generalidad, atender a particularidades como las que derivan de esta relación locaticia. A mayor abundamiento, es un régimen prácticamente inalterado en su totalidad desde su publicación en $1889^{28}$, un siglo en el que este tipo de arrendamiento, simplemente, no existía, ni tampoco las formas de contratación electrónica.

\footnotetext{
${ }^{27}$ Sobre esta cuestión, más ampliamente: MORENO-TORRES HERRERA, M.L. y MARTENS JIMÉNEZ, I.L., "Pasado, presente y futuro de la regulación de los arrendamientos de viviendas turísticas en el ordenamiento español”, op.cit, págs. 271-312.

${ }^{28}$ En efecto, el único artículo que ha sido modificado es el $1548 \mathrm{CC}$.
} 


\subsection{La inadecuación de los tipos de arrendamientos de vivienda a la realidad actual y la inadecuación de su regulación}

A la vista del régimen expuesto en el apartado anterior, cabe extraer las siguientes conclusiones, que se enumeran y desarrollan a continuación, y que indican que los tipos de arrendamientos de vivienda a los que actualmente se refiere la legislación española no son adecuados a la realidad sociológica imperante en nuestra sociedad. Se van a exponer, sin pretensiones de exhaustividad, las razones por las que la tipología actual es inadecuada.

2.2.A. Un solo arrendamiento de vivienda habitual, un solo arrendatario y un solo modelo de convivencia

En primer lugar, es preciso llamar la atención sobre el hecho de que la ley española reserva la denominación de "arrendamiento de vivienda" solo para aquellas viviendas en que se dan los requisitos, ya descritos, del art. 2 LAU, y ello al objeto de aplicarles un régimen jurídico de naturaleza imperativa que persigue, entre otras cosas, garantizar al inquilino una duración mínima de la relación contractual, algo que no ocurre cuando el destino del inmueble es satisfacer una necesidad transitoria de vivienda.

La tipología actual es inadecuada, por cuanto que ignora una realidad sociológica, a la que el régimen jurídico del arrendamiento de vivienda habitual, contenido en el Título II LAU, no se adapta. De los arts. 2, 7, 12, 15 y 16 LAU, es fácilmente apreciable que el arrendamiento de vivienda habitual al que se refiere la LAU está orientado a un modelo de convivencia familiar, de parentesco y/o conyugal, siendo así que la normativa se refiere al arrendatario en singular, sin prever situaciones de convivencia distintas a las mencionadas.

En efecto, el arrendamiento de vivienda tal y como está regulado en la LAU no contempla la tendencia en auge de compartir la vivienda con otras personas ajenas al núcleo familiar $^{29}$. El arrendamiento compartido por varios arrendatarios no es un fenómeno reciente, sí lo es, en cambio, su extensión a distintos perfiles de demandantes de vivienda. La evolución y aumento de la demanda de este tipo de arrendamiento se debe a que la idea de compartir la vivienda arrendada no es ya únicamente la elección de estudiantes, sino, muy por el contrario, la opción elegida (por voluntad o necesidad) por trabajadores y familias ${ }^{30}$. Existe también una tendencia, que ya se ha previsto en el Derecho alemán,

\footnotetext{
${ }^{29}$ En la "Encuesta continúa de hogares" (ECH) del año 2020 elaborada por el INE, se muestra que del año 2014 al año 2020 ha aumentado considerablemente el número de personas que deciden compartir vivienda. La encuesta no se refiere a arrendamientos, sino a hogares, por lo que las cifras también incluyen viviendas en propiedad. Así, en 2014 eran 372.900 los hogares de dos o más núcleos familiares, 554.500 los hogares de varias personas no familiares y 813.100 los hogares de un núcleo familiar con otras personas; mientras que en 2020 han sido, respectivamente, 443.300, 566.300 y 808.300 .

${ }^{30}$ En el Informe anual de pisos compartidos en España de 2019, efectuado por el portal: pisos.com, se detalla que la demanda es mayor en la franja de edad 18-25 años (51,31\%), seguido de la de 26-35 años (29,24 \%); siendo Madrid y Barcelona las ciudades con mayor demanda de viviendas compartidas. El
} 
de personas de avanzada edad que deciden compartir vivienda no solo para compartir gastos, sino por razones de índole más personal, como combatir la soledad a la que muchas se enfrentan. Buena prueba de la aparición de nuevos modelos de convivencia es que se encuentran, cada vez con mayor frecuencia, portales inmobiliarios que se dedican, exclusivamente, a anunciar habitaciones de viviendas para $\operatorname{arrendar}^{31}$, mientras que las tradicionales (idealista, fotocasa, etc.) permiten escoger el filtro para buscar arrendamientos compartidos. En la práctica, se han ido desarrollando otras fórmulas de convivencia como el alojamiento colaborativo o co-living ${ }^{32}$, huérfano, actualmente, de regulación.

La LAU no se refiere a este tipo de arrendamiento en el que conviven varias personas, incluso varias familias, sino que está pensado para aquel arrendamiento celebrado con un solo arrendatario, sin perjuicio de que conviva con sus familiares, es decir, cónyuge, persona de análoga relación de afectividad y/o hijos dependientes, que es a los que menciona la LAU. No se prevén cuáles deban ser las normas aplicables a un arrendamiento en el que no exista esa relación familiar, de parentesco, conyugal o de análoga relación de afectividad.

Dentro de la pluralidad de arrendatarios, deben diferenciarse dos situaciones: en primer lugar, el contrato de arrendamiento sobre la vivienda habitual celebrado entre el arrendador y varios arrendatarios, esto es, siendo todos ellos parte del contrato con la condición jurídica de arrendatarios; y aquellos otros arrendamientos que recaen sobre una habitación (o varias) de una vivienda arrendada, con derecho a usar las zonas comunes, tales como cocina, baño y salón.

\subsection{B. El arrendamiento de la vivienda habitual por varios arrendatarios}

Como se ha adelantado, son cada vez más las personas que optan por compartir la vivienda arrendada, ya sea por abaratar los costes o por otras razones de índole personal. En este primera modalidad de arrendamiento compartido, en el que se celebra un solo contrato en el que todos los coarrendatarios tienen la condición jurídica de arrendatarios respecto de la totalidad de la vivienda, el problema principal que refleja tanto el auge de este tipo de arrendamiento, como la necesidad de recogerlo y regularlo de forma adecuada, es la jurisprudencia vacilante de las audiencias provinciales sobre diferentes problemas jurídicos derivados de la necesidad de determinar qué tipo de obligación existe entre el arrendador y los distintos arrendatarios, de una parte, y entre los coarrendatarios, de otra. En ausencia de una norma que se refiera a la pluralidad de arrendatarios -

documento se puede consultar en: https://www.pisos.com/aldia/wp-content/uploads/2019/08/informe-pisocompartido-2019.pdf [Última fecha de consulta: 14 julio 2021]

${ }^{31}$ Por ejemplo, la plataforma «BADI» que se describe en su página web como "plataforma líder de alquiler de habitaciones a largo plazo".

${ }^{32}$ La plataforma en línea «HABYT», que nació en Alemania, ofrece tres tipos de arrendamiento distintos: el arrendamiento de la totalidad de una vivienda, el arrendamiento compartido y el arrendamiento colaborativo. Este último, según se indica en la propia plataforma, consiste en: dormitorio privado, zonas comunes de salón y comedor y acceso a eventos comunitarios. 
inexistente en la LAU y en los artículos que regulan el arrendamiento de cosas en el CCresultan de aplicación las normas generales contenidas en el $\mathrm{CC}$, en concreto, los arts. 1137 y $1138^{33}$, que hacen depender la solidaridad del pacto expreso contenido en el contrato. El problema es que esta regla general que proclaman los citados preceptos del CC ha sido matizada por el TS, abriendo las puertas a la llamada "solidaridad tácita" en la STS, Sala $1^{\text {a }}$, de 26 de noviembre de 2008 (ROJ: STS 6286/2008) ${ }^{34}$, confirmada por las SSTS de la Sala $1^{\text {a }}$, de 30 de julio de 2010 (ROJ: STS 4386/2010) ) $^{35}$ y de 15 de diciembre de 2017 (ROJ: STS 4440:2017) ${ }^{36}$. La solidaridad tácita implica que, aún a pesar de no constar expresamente en el contrato la voluntad de los contratantes de sujetarse a ella, se podrá apreciar la existencia de la misma "cuando entre los obligados se da una comunidad jurídica de objetivos manifestándose una interna conexión entre todos ellos a partir de las pruebas que en autos se practiquen o de la interpretación que los Tribunales puedan hacer de un determinado contrato y que hace inescindible el contrato" ${ }^{37}$. Queda en manos de los tribunales examinar en cada caso concreto las circunstancias que han concurrido, la relación existente entre las partes y apreciar la existencia de una voluntad si quiera tácita de solidaridad entre los deudores (en nuestro caso, arrendatarios).

En sede arrendaticia, la consecuencia -de una parte, previsible- ha sido una división entre los pronunciamientos de las audiencias provinciales que, aun a falta de mención alguna en el contrato y en supuestos muy similares, han considerado que existe mancomunidad ${ }^{38}$ o solidaridad $^{39}$, bien por una directa aplicación del art. $1137 \mathrm{CC}$, bien porque, siguiendo la doctrina del TS, tras analizar las circunstancias concretas, han estimado existente una

\footnotetext{
${ }^{33}$ Los arts. 1137 y 1138 del CC disponen, respectivamente, que "La concurrencia de dos o más acreedores o de dos o más deudores en una sola obligación no implica que cada uno de aquéllos tenga derecho a pedir, ni cada uno de éstos deba prestar íntegramente, las cosas objeto de la misma. Sólo habrá lugar a esto cuando la obligación expresamente lo determine, constituyéndose con el carácter de solidaria", y que "Si del texto de las obligaciones a que se refiere el artículo anterior no resulta otra cosa, el crédito o la deuda se presumirán divididos en tantas partes iguales como acreedores o deudores haya, reputándose créditos o deudas distintos unos de otros".
}

${ }^{34}$ ECLI:ES:TS:2008:6286.

${ }^{35}$ ECLI:ES:TS:2010:4386.

${ }^{36}$ ECLI:ES:TS:2017:4440.

${ }^{37}$ La consecuencia de esta interpretación se puede expresar con RAMÓN CHORNET, J.C., "Artículo 1137. Concurrencia de pluralidad de acreedores o deudores", en Código Civil Comentado, (dirs. Cañizares Laso, A., De Pablo Contreras, P., Orduña Moreno, F.J., y Valpuesta Fernández, R.), Cizur Menor, Thomson Reuters Aranzadi, 2a . ed., 2016, p. 273, en los siguientes términos: “¡a pesar de la rotunda disposición del art. 1137, el principal problema que plantea la solidaridad es determinar cuándo existe y cuándo no!”.

38 SAP de Burgos, Sección $3^{\text {a }}$, de 30 de septiembre de 2009 (ROJ: SAP BU 848/2009; ECLI:ES:APBU:2009:848); SAP de Ciudad Real, Sección 1a., de 4 de abril de 2014 (ROJ: SAP CR 325/2014; ECLI:ES:APCR:2014:325); SAP de Santa Cruz de Tenerife, Sección 1a. ${ }^{\text {., de }} 27$ de mayo de 2014 (ROJ: SAP TF 1770/2014; ECLI:ES:APTF:2014:1770).

${ }^{39}$ STS de 26 de noviembre de 2008, op.cit.; STS de 30 de julio de 2010, op.cit.; SAP de Valencia, Sección $6^{\mathrm{a}}$., de 17 de febrero de 2006 (ROJ: SAP V 4723/2006; ECLI:ES:APV:2006:4723); SAP Barcelona, Sección 4a., de 9 de octubre de 2012 (ROJ: SAP B 14273/2012; ECLI:ES:APB:2012:14273); SAP Barcelona, Sección 4a., de 14 de febrero de 2012 (ROJ: SAP B 1924/2012; ECLI:ES:APB:2012:1924); SAP de Barcelona, Sección 4a ${ }^{\text {, }}$ de 5 de febrero de 2013 (ROJ: SAP B 550/2013; ECLI:ES:APB:2013:550); SAP de Tarragona, Sección 3a, de 12 de junio de 2018 (ROJ: SAP T 728/2018; ECLI:ES:APT:2018:728). 
voluntad favorable a la mancomunidad o la concurrencia de una voluntad tácita de solidaridad de las obligaciones contenidas en el contrato.

Esta disparidad de criterios es consecuencia directa de la admisión de la solidaridad tácita, que podría resolverse con una previsión normativa $a d$ hoc, ya que la LAU no ha previsto que cada vez más personas optarían por esta vía de acceso a la vivienda, centrándose exclusivamente en un modelo tradicional del arrendamiento de la vivienda habitual en cuanto a los demandantes y la demanda de vivienda.

Como principal crítica cabe enumerar los tres efectos que, según CARRASCO PERERA $^{40}$ genera la interpretación por el TS del art. 1137 CC o más bien la tácita derogación del contenido de este precepto que ha provocado con ella ${ }^{41}$. Así, en primer lugar, cabe señalar que, mediante la interpretación efectuada por el TS, se consigue una protección excesiva a favor del acreedor a costa del deudor que, por regla general, ya ocupa la posición más débil de la relación ${ }^{42}$. En segundo lugar, y partiendo de la base de que en la mayoría de los supuestos los arrendatarios no se conocen con anterioridad a la firma del contrato, cabe pensar que no es su voluntad responsabilizarse de los incumplimientos de los demás arrendatarios. Finalmente, y en relación con el punto anterior, no cabe duda de que cada uno de los arrendatarios celebrará su contrato con la intención de ejercitar libremente sus derechos y no quedar sometido a las decisiones de los demás arrendatarios.

Esta y otras particularidades derivadas de un arrendamiento con varios arrendatarios cotitulares del mismo, deben quedar reguladas, sobre todo, a la vista de la inseguridad jurídica y la litigiosidad que ha generado la falta de previsión de este supuesto.

\subsection{El arrendamiento de habitaciones con derecho a usar zonas comunes}

Aparte de las plataformas ya indicadas, se puede apreciar el auge de este tipo de arrendamiento de vivienda en la jurisprudencia de las audiencias provinciales, que se han enfrentado a la tesitura de valorar si en estos supuestos el arrendamiento es de vivienda habitual, aplicando la normativa proteccionista, o si en cambio no se puede considerar como tal por no concurrir en el caso concreto los requisitos del art. 2 LAU. En este último

40 CARRASCO PERERA, A., “Artículo 1137”, en Comentarios al Código Civil, Tomo VI, (coord. Bercovitz Rodríguez-Cano, R.), Valencia, Tirant lo Blanch, 2013, págs. 8363-8364.

${ }^{41}$ A este respecto, manifiesta CARRASCO PERERA, A., "Artículo 1137”, en Comentarios al Código Civil, op.cit., pág. 8364: “es sabido, en cambio, que la jurisprudencia superó hace ya tiempo esta norma de no presunción de solidaridad, de forma que puede decirse que en la actualidad el art. 1137 CC ha perdido vigencia por mor de una jurisprudencia contra legem que ya se ha convertido en fuente supletoria del Derecho, con el respaldo o sin él del art. 1.3 CC".

42 De hecho, en la SAP de Barcelona de 5 de febrero de 2013, op.cit., la Audiencia hace referencia, en su fundamento $2^{\circ}$, con cita del TS, a la posibilidad de deducir la solidaridad de la propia naturaleza de lo pactado, sobre todo, cuando se busca facilitar la garantía de los acreedores, y reitera esta idea en su fundamento $4^{\circ}$ mencionado el «plus de garantía» a favor del acreedor. Concluyendo que "Las relaciones entre arrendador y arrendatario, por su naturaleza y la del objeto sobre que recaen, revisten carácter solidario salvo que se demuestre que la voluntad de las partes fue otra (pacto lícito, por supuesto)”. 
caso se plantea si se trata de un arrendamiento para uso distinto del de vivienda y, por tanto, se aplicaría la regulación del Título III LAU o si, directamente, debe quedar excluido del ámbito de aplicación de la ley especial, y sometido al régimen del $\mathrm{CC}$, con la evidente desprotección que deriva de esta decisión.

No ofrece el legislador mayor aclaración sobre estos dos elementos a que se refiere el art. 2 LAU, por lo que, a efectos de determinar si el arrendamiento por habitaciones tiene cabida, o no, dentro de ese concepto, han sido las audiencias provinciales las que, al interpretar la norma y aplicarla a los casos concretos (cfr. art. 6.1 CC), han ido precisándolo. No existe, sin embargo, unanimidad en la jurisprudencia menor, sino soluciones dispares. De hecho, las abundantes sentencias son prueba, nuevamente, de la generalización de esta modalidad de convivencia y de la litigiosidad que se ha derivado de la falta de previsión legal. La mayoría de las sentencias resuelven que el arrendamiento por habitaciones no lo es de vivienda habitual, en el sentido del art. 2 LAU. Es esta también la postura mayoritaria de la doctrina ${ }^{43}$.

Fundamentalmente, el argumento usado para justificar que no se trata de un arrendamiento de vivienda habitual es que, al recaer solo sobre una habitación, aun a pesar de permitirse también el uso de otras habitaciones tales como la cocina, el baño y el salón, no se cumple con los requisitos de habitabilidad ${ }^{44}$. Se definen estos en la jurisprudencia en función de que la edificación sea "adecuada a servir a las necesidades de morada o residencia, donde la persona o familia desarrollan la intimidad de su existencia, constituyendo su hogar o sede de la vida doméstica" ${ }^{45}$. Por otra parte, y queda así cerrada la argumentación de las audiencias, según doctrina del $\mathrm{TS}^{46}$, en caso de duda

\footnotetext{
${ }^{43}$ VALLADARES RASCÓN, E. y ORDÁS ALONSO, M., "Artículo 2.1. Arrendamiento de vivienda", op.cit., pág. 80, BOTELLO HERMOSA, J.M., "El contrato de arrendamiento de habitación: la problemática de su regulación. ¿Ley de Arrendamientos Urbanos o Código Civil?, Revista Crítica de Derecho Inmobiliario, núm. 754, 2016, págs. 51-52; SIMÓN MORENO, H., "Propuestas de regulación para habitar parcialmente una vivienda", en El acceso a la vivienda en un contexto de crisis, (dir. Nasarre Aznar, S. y coord. Simón Moreno, H.), Madrid, Edisofer, 2011, págs. 226-229.
}

44 SAP Madrid, Sección 11a., de 26 de septiembre de 2017 (ROJ: SAP M 12601/2017; ECLI:ES:APM:2017:12601); SAP Madrid, Sección 14 ${ }^{\mathrm{a}}$., de 27 de marzo de 2012 (ROJ: SAP M 5397/2012; ECLI:ES:APM:2012:5397); SAP Madrid, Sección 14, de 13 de diciembre de 2006 (ROJ: SAP M 16230/2006; ECLI:ES:APM:2006:16239); SAP Madrid, Sección 9a., de 28 de marzo de 2019 (ROJ: SAP M 2936/2019; ECLI:ES:APM:2019:2936); SAP Madrid, Sección 14 ${ }^{\text {a }}$, de 10 de julio de 2007 (ROJ: SAP M 8930/2007; ECLI:ES:APM:2007:8930); SAP Madrid, Sección 25a., de 14 de abril de 2014 (ROJ: SAP M 6122/2014; ECLI:ES:APM:2014:6122); SAP Ciudad Real, Sección 1 ${ }^{\mathrm{a}}$., de 14 de septiembre de 2017 (ROJ: SAP CR 891/2017; ECLI:ES:APCR:2017:891); SAP Valladolid, Sección 3a ${ }^{\mathrm{a}}$, de 15 de diciembre de 2015 (ROJ: SAP VA 1306/2015; ECLI:ES:APVA:2015:1306); SAP Barcelona, Sección $4^{\mathrm{a}}$., de 8 de mayo de 2008 (ROJ: SAP B 4276/2008; ECLI:ES:APB:2008:4276); SAP Barcelona, Sección 4ª ., de 7 de junio de 2012 (ROJ: SAP B 7857/2012; ECLI:ES:APB:2012:7857); SAP Islas Baleares, Sección 3a ${ }^{\text {a }}$, de 20 de mayo de 2010 (ROJ: SAP IB 1022/2010; ECLI:ES:APIB:2010:1022); SAP Vizcaya, Sección 5a․, de 21 de julio de 2006 (ROJ: SAP BI 1554/2006; ECLI:ES:APBI:2006:1554); SAP Las Palmas, Sección 3ª., de 7 de octubre de 2008 (ROJ: SAP GC 2635/2008; ECLI:ES:APGC:2008:2635).

${ }^{45}$ SAP Madrid de 10 de julio de 2007, op.cit.

${ }^{46}$ Por todas, la STS, Sala $1^{\text {a }}$., de 10 de febrero de 1986, (ROJ: STS 530/1986; ECLI:ES:TS:1986:530) fj $1^{\circ}$ : "... que los supuestos en los que exista duda acerca de si la normativa aplicable a un contrato es la general del Código Civil, o la especial, representada en este caso por la Ley de Arrendamientos Urbanos, es obvio que debe concluirse la aplicabilidad de la legislación general dictada para la mayoría de los casos, en lugar 
sobre la aplicabilidad de la ley especial o de la norma general, debe recurrirse a esta última que es la que tiene mayor ámbito de aplicación. Ahora bien, otras audiencias provinciales $^{47}$, centrándose en el requisito de la destinación del arrendamiento hacia la satisfacción de la necesidad permanente de vivienda, entienden que a la vista de la concurrencia en los arrendatarios de habitaciones de, precisamente, esa necesidad, los consideran merecedores de la protección contenida en la LAU. Se apoyan, además, en la literalidad de la norma que, pudiendo haber incluido como requisito que el arrendamiento recayera sobre la totalidad de la vivienda, excluyendo el arrendamiento parcial, no lo hizo.

La relevancia de la conceptualización del arrendamiento por habitaciones como un arrendamiento de vivienda habitual es, como ya se adelantaba, nada menos que un régimen imperativo y proteccionista $o$, muy por el contrario, un régimen sometido a la libre voluntad de las partes. Las consecuencias se reflejan también en otros ámbitos, por ejemplo, significa cerrar las puertas del Registro de la Propiedad a este tipo de arrendamientos, puesto que no admite la inscripción de un arrendamiento exclusivamente sobre una habitación de una vivienda ${ }^{48}$.

Apoya el arraigo de este tipo en nuestra sociedad, el hecho de que en Cataluña ya se ha previsto su existencia en su Ley de vivienda. Recientemente, se ha modificado la Ley 18/2007, de 28 de diciembre, de derecho a la vivienda, por virtud del Decreto Ley 50/2020, de 9 de diciembre. Se introducen los denominados "alojamientos con espacios comunes complementarios" 49 , indicando los requisitos de habitabilidad que deben concurrir. Se explica en la Exposición de Motivos del Decreto ley que para conseguir la finalidad de facilitar el acceso a la vivienda de alquiler en todos sus niveles (social, asequible o libre), una de las vías es la configuración jurídica de los alojamientos con espacios comunes complementarios, aclarando que, si bien hay una importante demanda "hoy no tiene encaje en el actual marco normativo porque no las prevé".

de seguir el criterio de la especialidad que representa la aplicación de las normas sociales que componen la Ley de Arrendamientos Urbanos". Así también en la STS, Sala 1ª, núm. 47/2000, de 24 de enero de 2000 (ROJ: STS 308/2000; ECLI:ES:TS:2000:308).

47 SAP Islas Baleares, Sección 4 $4^{\mathrm{a}}$, de 12 de junio de 2018 (ROJ: SAP IB 1112/2018; ECLI:ES:APIB:2018:1112); SAP Zaragoza, Sección 5 ${ }^{\mathrm{a}}$., de 26 de octubre de 2006 (ROJ: SAP Z 2355/2006; ECLI:ES:APZ:2006:2355); SAP Barcelona, Sección 4a., de 18 de mayo de 2005 (ROJ: SAP B 5124/2005; ECLI:ES:APB:2005:5123); SAP Santa Cruz de Tenerife, Sección $4^{\mathrm{a}}$,, de 19 de abril de 2004 (ROJ: SAP TF 761/2004; ECLI:ES:APTF:2004:761); SAP Lugo, Sección 2a ${ }^{\text {a }}$ de 5 de diciembre de 2005 (ROJ: SAP LU 1241/2005; ECLI:ES:APLU:2005:1241); SAP Asturias, Sección 7a ., de 7 de septiembre de 2005 (ROJ: SAP O 3419/2005; ECLI:ES:APO:2005:3419).

${ }^{48}$ RDGRN de 29 de septiembre de 2017.

${ }^{49} \mathrm{El}$ art. 3 los define como: "la vivienda que, de acuerdo con la normativa de habitabilidad, tiene una superficie del espacio privativo inferior a la fijada para el resto de tipologías de vivienda y que dispone de unos espacios comunes complementarios ajustados a los requisitos mínimos y de calidad establecidos en la normativa mencionada" y los espacios complementarios: "los espacios de uso compartido de un edificio, otros que los elementos comunes establecidos como obligatorios por la normativa que, de acuerdo con el nivel de calidad exigido por la normativa de habitabilidad, complementan el uso y disfrute de los espacios privativos de todos o parte de las viviendas o alojamientos que comprende el edificio". 
2.2.D. Cooperativas de vivienda en régimen de cesión de uso

Al objeto de valorar la adecuación o inadecuación de nuestro sistema arrendaticio a la realidad social y su coherencia con el resto del ordenamiento jurídico, interesa además señalar que puede ocurrir que la vivienda arrendada sea propiedad de una cooperativa de viviendas. Las normas estatales y autonómicas reguladoras de las cooperativas suelen incluir disposiciones específicas para las llamadas cooperativas de viviendas. Así, la Ley estatal 27/1999, de cooperativas, les dedica cuatro artículos, entre los que se recoge la posibilidad que aquí interesa y que consiste en la cesión del uso de la vivienda a los socios por la cooperativa, que retiene la propiedad de la misma.

En concreto, el art. 89 Ley de Cooperativas dispone que: "3. La propiedad o el uso y disfrute de las viviendas y locales podrán ser adjudicados o cedidos a los socios mediante cualquier título admitido en Derecho. Cuando la cooperativa retenga la propiedad de las viviendas o locales, los Estatutos establecerán las normas a que ha de ajustarse tanto su uso y disfrute por los socios, como los demás derechos y obligaciones de éstos y de la cooperativa, pudiendo prever y regular la posibilidad de cesión o permuta del derecho de uso y disfrute de la vivienda o local con socios de otras cooperativas de viviendas que tengan establecida la misma modalidad".

En la práctica, esta modalidad está despertando el interés tanto de posibles usuarios, como de la doctrina que ha comenzado a analizar y estudiar esta figura. Se reconoce en el régimen de cesión de uso de las viviendas la materialización en nuestro ordenamiento de la llamada vivienda colaborativa ${ }^{50}$.

Ahora bien, la figura suscita cuestiones que no están resueltas por el legislador. En principio, parece que las disposiciones estatutarias desplazarían a las normas de la Ley de arrendamientos urbanos, que quedarían sin aplicación, pero surge la duda de la normativa aplicable en lo no previsto por los estatutos. En otras palabras, se hace preciso determinar el contenido de la relación que surge entre la cooperativa y el socio usuario de la vivienda, que presenta diferencias con la existente entre arrendador y arrendatario. También es necesario establecer cuál es el juego del principio de autonomía de la voluntad en este ámbito.

2.2.E. El arrendamiento de vivienda no habitual. El denominado "arrendamiento de temporada"

En este supuesto, la inadecuación deriva de la propia falta de una tipología más amplia, la LAU solo se refiere a un tipo de arrendamiento de vivienda, por lo que, necesariamente, el arrendamiento de temporada tiene que incluirse entre los arrendamientos "para uso distinto al de vivienda" del art. 3 LAU, que los somete a la regulación establecida en el

${ }^{50}$ SIMÓN MORENO, H., "Las cooperativas de viviendas en régimen de cesión de uso: ¿una alternativa real a la vivienda en propiedad y en alquiler en España?", REVESCO. Revista de Estudios Cooperativos, vol. 134, 2020, e69165, pág.2, DOI: https://dx.doi.org/10.5209/REVE.69165. 
Título III, claramente diseñada para un arrendamiento de un local en el que se ejerza una actividad comercial o profesional, como ya se ha explicado.

Esta modalidad de arrendamiento urbano, que también recae sobre una vivienda, no es, en absoluto, una figura de nueva aparición en nuestra sociedad. No obstante, no ha conseguido aun el legislador establecer un régimen adecuado para estos arrendamientos. Muy por el contrario, los ha relegado a compartir el régimen de los arrendamientos para uso distinto de vivienda, situándolos en el mismo grupo de arrendamientos, que, indudablemente, está diseñado para atender las necesidades de arrendatarios de espacios en los que se ejerce una actividad empresarial (vid. apartado anterior para ejemplos de artículos del Título III).

\subsection{F. El arrendamiento de una vivienda turística}

Con la normativa actual, en concreto, con el desafortunado art. 5 LAU, se genera una situación de dualidad de regímenes para el arrendamiento de una vivienda turística, ya sea el CC o el Título III LAU. En cualquier caso, ninguno de los dos regímenes posibles a los que puede quedar sometida la relación contractual se creó para los concretos problemas que pueden plantearse en ella. Baste recordar que el CC es del año 1889 y sus redactores no pensaron en absoluto -ni naturalmente podían- en el arrendamiento de viviendas turísticas. No podían prever la necesidad de regular la cancelación de la reserva $^{51}$, el desistimiento, entre otros muchos aspectos propios y exclusivos de este tipo de arrendamiento de vivienda. Tampoco el Título III LAU puede responder a las particularidades de este tipo de arrendamiento pues, como ya se ha explicado en el apartado anterior, es heredero de una regulación que se centraba exclusivamente en los locales de negocio. El régimen que actualmente se aplica a los arrendamientos de viviendas turísticas, tanto si es el del CC como si es el del "arrendamiento para uso distinto de vivienda" no resuelve los particulares problemas que estos arrendamientos turísticos $\operatorname{suscitan}^{52}$.

\section{LOS TIPOS DE ARRENDAMIENTOS DE VIVIENDA EN EL DERECHO ALEMÁN ${ }^{53}$}

Al objeto de formular propuestas dirigidas a mejorar el sistema arrendaticio español, conviene conocer las soluciones adoptadas en otros países, sobre todo, aquellos que

\footnotetext{
${ }^{51}$ Para un estudio detallado sobre la cancelación de la reserva se puede consultar: GÁLVEZ CRIADO, A., "El derecho de cancelación del usuario de la reserva de alojamientos turísticos", Revista de Estudios Jurídicos y Criminológicos, núm. 3, Universidad de Cádiz, 2021, págs. 65-102, DOI: http://doi.org/10.25267/REJUCRIM.2021.i3.4.

${ }^{52} \mathrm{Al}$ igual que respecto del arrendamiento de la vivienda habitual, el arrendamiento de habitaciones también suscita importantes cuestiones jurídicas en el ámbito del arrendamiento turístico. En este sentido, se puede consultar QUESADA SÁNCHEZ, A., "La cesión de viviendas turísticas por habitaciones: situación legal en España y propuestas razonables”, Revista Crítica de Derecho Inmobiliario, núm. 783, 2021, págs. 279313.

${ }^{53}$ Nota aclaratoria sobre la cita de la bibliografía alemana: se ha seguido el sistema de citas alemán para facilitar la consulta de la bibliografía citada en este artículo, y que consiste en exponer la "Rn" que es el
} 
cuenten con una regulación completa y reciente y en la que la opción del arrendamiento sea una verdadera alternativa a la compraventa para acceder a la vivienda. El ordenamiento alemán responde a ambas premisas, por lo que resulta oportuno su estudio.

Con carácter previo, cabe llamar la atención sobre el hecho de que la evolución del Derecho arrendaticio alemán ha sido similar a la del Derecho español, en el sentido de que, si bien el Código civil alemán (en adelante, BGB) ha recogido desde su primera redacción la regulación del arrendamiento, lo cierto es que la evolución de las necesidades económicas y de la sociedad han inspirado al legislador alemán a dictar leyes de modificación de las normas contenidas en el mismo, algunas con mayor alcance y duración, así como leyes especiales para regular aspectos concretos como la protección del arrendatario frente a la extinción sin justa causa por el arrendador; o la limitación del precio del alquiler. Finalmente, ante la dispersión de las distintas modificaciones y leyes especiales, se hizo necesario modificar el BGB para adecuarlo a la realidad social y económica y para simplificar la regulación sobre arrendamientos, unificándola en un solo cuerpo legal. La nota diferenciadora entre la evolución española y la alemana es que la regulación sobre arrendamientos está recogida actualmente solo en el BGB, exceptuándose únicamente aquellos que, por pertenecer al ámbito público, no tienen cabida en un Código de Derecho privado ${ }^{54}$, mientras que en el Derecho español es la ley especial, la LAU, la que se refiere a los arrendamientos de vivienda, en la forma ya explicada, siendo el CC supletorio, salvo para aquellos tipos que queden excluidos del ámbito de aplicación de la LAU.

Concretando aún más lo expresado en las líneas anteriores, el BGB se centra especialmente en el arrendamiento de viviendas (Wohnraummietrecht $)^{55}$, para el que establece, implícitamente, distintos tipos, según la finalidad perseguida, la duración y los intereses intervinientes en la relación arrendaticia, como se explicará a continuación. Fuera de los distintos supuestos de arrendamiento que pueden recaer sobre una vivienda, se regulan también por el BGB el arrendamiento de los denominados "Räume", que se puede traducir como estancias o habitaciones, sin que deba confundirse con estancias destinadas a vivienda; y arrendamientos sobre solares, locales y barcos, que escapan al estudio pretendido, pero que sirven de indicio sobre el empeño del legislador alemán en

número del apartado que contiene la cita y el artículo o parágrafo comentado, así como el autor que realiza el comentario. Respecto de las leyes, se indica el Boletín en el que ha sido publicada. Las Exposiciones de Motivos se han citado con el nombre original "Drucksache" y la referencia.

${ }^{54}$ Drucksache 45/4553, p. 35.

${ }^{55}$ Se habla de arrendamientos de vivienda (Wohnraummiete) cuando las distintas habitaciones que se ceden en arrendamiento deben servir a las necesidades de vivienda del arrendatario y/o de su familia (BLANK, "Vorbemerkung zu §535 BGB”, en Mietrecht, (dir. Schmidt-Futterer), München, C.H. Beck, 14a . ed, 2019, Rn. 94; BRUNS, “\$549 Auf Wohnraummietverhältnisse anwendbare Vorschriften”, en BeckOK Mietrecht, (dir. Schach, Schultz y Schüller), 2021, Rn. 2). No obstante, debe tenerse en cuenta la diferencia entre los términos "Wohnraum" y "Wohnung", pues, como explica BLANK ("Vorbemerkung zu §535 BGB", op.cit., Rn. 101) bajo "Wohnraum" se engloba cualquier espacio o habitación que se arriende con finalidad de servir como vivienda, mientras que la "Wohnung" es aquel conjunto de habitaciones que permiten la llevanza personal y económica de un hogar (Haushalt), lo cual incluye la cocina, agua, etc. 
establecer una normativa apropiada para cada arrendamiento en función del objeto sobre el que recae y la finalidad a la que se destine el mismo.

Basta con consultar el índice del BGB, para conocer la sistemática que sigue este cuerpo legal para regular el arrendamiento: se establecen disposiciones generales aplicables a todos los tipos de arrendamiento, con independencia de su objeto ( $§ 535$ a 548 BGB), salvo que queden expresa o tácitamente modificados por las normas específicas; en segundo lugar, normas especificas para los arrendamientos que tienen por objeto una vivienda ( $\S 549$ a 577.a BGB); y, finalmente, las normas para aquellos arrendamientos que tienen por objeto otras cosas -las ya mencionadas estancias, solares, locales y barcos( $\S 578$ a 580.a BGB). Esta estructura, que se introdujo en el BGB para aportar claridad y facilitar la regulación de los arrendamientos, fue obra de la Ley de reforma del arrendamiento de 19 de junio de $2001^{56}$. Hasta ese año en el BGB no se diferenciaba según el objeto sobre el que recayera el arrendamiento ${ }^{57}$, mientras que en diversas leyes especiales se recogían normas específicas, sobre todo, para los llamados arrendamientos de vivienda ${ }^{58}$, para los que, a partir del año 1960, se había iniciado la constitución de un Derecho de arrendamiento de vivienda de carácter social (soziales Wohnraummietrecht), que es aquel que tiene por objeto la vivienda concebida como el punto central de la vida del individuo (Lebensmittelpunkt), lo que hacía necesario establecer una normativa adecuada a la importancia que para el individuo representa dicha vivienda. Tanto es así, que el arrendamiento de vivienda se equipara, en cuanto a la protección que merece, al derecho de propiedad que regula el art. 14 de la Constitución alemana ${ }^{59}$ (en adelante,

\footnotetext{
${ }^{56}$ En efecto, en la Exposición de motivos de la Ley de Reforma del Arrendamiento de 2001 (Gesetz zur Neugliederung, Vereinfachung und Reform des Mietrechts o Mietrechtsreformgesetz, BGBI. I 2001 pág. 1149) se explica que las distintas modificaciones efectuadas en los años 1960, 1963, 1964, 1967, 1971, 1974, 1982, 1990, 1993, 1995 y 1996 habían creado un régimen disperso, sobre todo, referente a aquellos arrendamientos cuyo objeto fuera una vivienda, de tal manera que diferentes normas esenciales del régimen del arrendamiento de vivienda estaban repartidas en varias leyes especiales, y no en el BGB. (Drucksache 43/4335, págs. 34-35).

${ }^{57}$ Con anterioridad a la reforma, en el $2^{\circ}$ Libro del BGB, apartado $7^{\circ}$, Título $3^{\circ}$ se regulaba en el capítulo I el alquiler, en los $\S \S 535-580 \mathrm{a}$, sin subdividirlo en capítulos, como se hace a partir de la reforma.

${ }^{58}$ Por ejemplo, se regulaba la protección frente a la declaración de extinción del arrendamiento por el arrendador y frente a la modificación al alza de la renta, salvo para equipararla a la renta comparativa, en la Ley de 25 de noviembre de 1971, sin embargo, dado que su vigencia era limitada (hasta el 31 de diciembre de 1974), y a la vista de los resultados positivos que se habían logrado con ella, se dictó la Ley de 21 de diciembre de 1974 que se encargaría de introducir la normativa en el BGB. De hecho, en la Exposición de Motivos de la Ley de 1974 se indica que, aunque fuera temporal la primera ley, era recomendable trasladar la normativa al BGB, a la vista de la disminución de los procedimientos judiciales (Drucksache 7/2011, pág. 7).

${ }^{59} \mathrm{El}$ art. 14 de la Constitución alemana establece que: “(1) La propiedad y el derecho a la herencia están garantizados. Su contenido y sus límites serán determinados por las leyes. (2) La propiedad obliga. Su uso debe servir al mismo tiempo al bien común. (3) La expropiación está permitida sólo por razones de bien común. Podrá ser efectuada sólo por ley o en virtud de una ley que establezca el modo y el monto de la indemnización. La indemnización se fijará considerando en forma equitativa los intereses de la comunidad y de los afectados. En caso de discrepancia sobre el monto de la indemnización quedará abierta la vía judicial ante los tribunales ordinarios".
} 
GG), sobre todo, a partir de la doctrina sentada en la sentencia de 26 de mayo de 1993 del Tribunal constitucional alemán ${ }^{60}$ (en adelante, BVerfG).

Es esta la razón fundamental que hacía necesaria, según el legislador alemán, una nueva estructura para la regulación de los arrendamientos ${ }^{61}$, sin perjuicio del contenido que también debía unificarse y, sobre todo, modernizarse, pues al igual que ocurre respecto de la regulación del arrendamiento en el CC español, la regulación contenida en nuestros respectivos códigos es muy antigua, el año 1896, en el caso del BGB, y el año 1889, respecto del $\mathrm{CC}$ español. Mientras que en la regulación del arrendamiento español que recoge el CC solo se ha modificado un artículo desde que se publicara a finales del siglo XIX $^{62}$, el legislador alemán, en el año 2001 apreció la acuciante necesidad de modernizarlo. De hecho, en la Exposición de Motivos de la Ley de 2001 se explica que desde el año 1896, las relaciones sociales y económicas han cambiado sobremanera y los intereses merecedores de protección respecto de cada una de las partes del contrato se han ido desplazando.

De una lectura detallada de la normativa, cabe diferenciar, por un lado, entre arrendamientos que recaen sobre la vivienda, cuando esta debe servir como el lugar que representa el centro de la vida del individuo, a los que les resultan aplicables la totalidad de la normativa proteccionista diseñada por el legislador alemán, sin perjuicio de que,

\footnotetext{
${ }^{60}$ En concreto, la interpretación que hace el Tribunal Constitucional alemán, en la sentencia de 26 de mayo de 1993 (Ref.: 1 BvR 208/93), consiste en equiparar el derecho de propiedad y el derecho posesorio del arrendatario, pues ambos recaen sobre la vivienda que no es sino el eje central de la vida del individuo y como tal merece la máxima protección jurídica, que se manifiesta a través de diversos mecanismos: de un lado, el mandato al legislador de procurar la protección oportuna del derecho del arrendatario, plasmándola en la legislación; y, de otro, legitimando al arrendatario para ejercitar su derecho a tutela judicial no solo ante los tribunales civiles ordinarios, sino incluso ante el BVerfG con base en dicho art. 14 GG. Los principales fundamentos jurídicos que llevan a la respuesta afirmativa del BVerfG de que el derecho posesorio derivado del contrato de arrendamiento sobre la vivienda arrendada constituye propiedad en el sentido del art. $14 \mathrm{GG}$, y por ende, merecedor de la garantía que recoge dicho precepto son los siguientes: en primer lugar, aclara qué debe entenderse por "propiedad" en el sentido que le atribuye el art. 14 GG, pues se refiere a todo derecho patrimonial que faculte a su titular para el uso privado y propio de la cosa. En cuanto a la garantía que el art. 14 del GG ofrece para el titular del derecho correspondiente, consiste en permitirle desarrollar su vida privada de forma independiente (FD 2.a). En segundo lugar, señala que la vivienda constituye el punto central de la existencia de cada particular, pues es en esta vivienda en la que el particular desarrolla su personalidad, con independencia y libertad, y satisface las necesidades básicas de su vida. Sin embargo, y por ello se entiende aplicable el art. $14 \mathrm{GG}$ al arrendamiento, recuerda que no todas las personas pueden adquirir una vivienda en propiedad, sino que debe recurrir a otras vías de acceso a la vivienda, en concreto, al arrendamiento. Para el arrendatario, el derecho de posesión que deriva de la celebración del contrato de arrendamiento, supone la vía para conseguir ese desarrollo de su personalidad y la satisfacción de sus necesidades básicas.

${ }^{61}$ Drucksache 14/4553, pág. 35.

${ }^{62}$ El único artículo del CC que ha sido reformado en materia de arrendamientos es el art. 1548 que en su redacción original establecía: "El marido relativamente a los bienes de su mujer, el padre y tutor respecto a los del hijo o menor, y el administrador de bienes que no tenga poder especial, no podrán dar en arrendamiento las cosas por término que exceda de seis años", fue modificado en $1975 \mathrm{y}$, nuevamente, en 2021 , a través de la Ley 8/2021, de 2 de junio, por la que se reforma la legislación civil y procesal para el apoyo a las personas con discapacidad en el ejercicio de su capacidad jurídica. La redacción actual establece que: "Los progenitores o tutores, respecto de los bienes de los menores, y los administradores de bienes que no tengan poder especial, no podrán dar en arrendamiento las cosas por término que exceda de seis años."
} 
como veremos, haya establecido particularidades para los supuestos en que el arrendamiento sea de duración determinada o se trate de una vivienda arrendada al trabajador del arrendador. Por otro lado, habida cuenta de que hay arrendamientos que pueden recaer sobre una vivienda, sin que esta represente el punto central de la vida del individuo, y que, por ende, no requieren de un nivel máximo de protección, el legislador alemán ha determinado distintos tipos, especificando cuáles son las normas que no resultarán aplicables de ese régimen social y proteccionista. Se encarga de ello el $\S 549$ $\mathrm{BGB}^{63}$.

En definitiva, el grado máximo de protección se atribuye en el ordenamiento alemán para el caso en que la vivienda es el centro de la vida del individuo y se concreta en los siguientes derechos: limitación de la renta, extinción del contrato a instancia del arrendador solo si existe un motivo importante, y posibilidad del arrendatario de oponerse a la extinción alegando un perjuicio grave. Precisamente, para los tipos que señala el parágrafo $549 \mathrm{BGB}$, se dispone la no aplicación de las normas de protección, por estimarse innecesarias ${ }^{64}$-por distintas razones que se analizarán por separado- o, al menos, en su totalidad. Parece conveniente, por tanto, exponer brevemente en qué consisten estas medidas proteccionistas y el alcance que tienen respecto de la libertad de pacto para los contratantes.

\subsection{El arrendamiento de la vivienda que sea el centro de la vida del individuo: principales medidas proteccionistas}

\subsection{A. Las causas de extinción del contrato y el derecho de oposición del arrendatario}

Por regla general, el arrendamiento de vivienda en el Derecho alemán es de duración indefinida, estableciendo el legislador causas ordinarias y extraordinarias que permiten al arrendador extinguir el contrato, cumpliendo con unos requisitos de forma y plazo. El contrato es de duración indefinida por cuanto que el objeto del mismo es la vivienda como centro de la vida del arrendatario, quien, en principio, pretende establecerse en esa vivienda y en esa zona urbana con vocación de permanencia. Mientras que al arrendador no se le causan mayores perjuicios si el arrendatario decide abandonar la vivienda, ya que

\footnotetext{
${ }^{63}$ Con anterioridad a la reforma efectuada en el año 2001, las distintas excepciones a las normas para los tipos de arrendamientos que recayeran sobre una vivienda, se anunciaban en cada uno de los artículos de la regulación, lo que complicaba en exceso una visión global sobre las excepciones a las normas generales. Por ejemplo, en la versión vigente entre el 1 de marzo de 1996 al 1 de septiembre de 2001, se enumeran en el parágrafo 564b BGB las causas que permiten al arrendador dar por terminado el arrendamiento, diferenciando entre arrendamientos de vivienda en sentido estricto y otros arrendamientos que recaen sobre una vivienda, pero en los que concurren circunstancias especiales, ya sea por la duración, o por tratarse de un arrendamiento compartido con el propietario de la vivienda. En estos casos, las causas para dar por terminado el contrato son distintas. De hecho, para la mayoría de los supuestos, directamente se aclara que la normativa anterior no resultará aplicable a los arrendamientos enumerados. A raíz de la modificación se recogen en un solo artículo, el § $549 \mathrm{BGB}$, los distintos tipos de arrendamiento sobre viviendas que existen, y las normas que resultan aplicables o, más concretamente, las que no resultan aplicables.

${ }^{64}$ Como confirma la Exposición de Motivos de la Ley de 2001, las excepciones a la aplicación de la normativa referida a los arrendamientos de vivienda se concretan en la protección del arrendatario frente a la resolución por el arrendador y las limitaciones al precio del alquiler (Drucksache 14/4553, p. 45).
} 
este deberá notificarlo con tiempo suficiente para que el arrendador pueda buscar un arrendatario alternativo; para el arrendatario, asentado en esa vivienda y en la zona urbana, una extinción por parte del arrendador sí puede tener consecuencias relevantes. Sobre todo, a la vista de la dificultad en muchos casos de encontrar una vivienda de similares características que esté ubicada en la misma zona en la que el arrendatario ya había establecido lazos con el entorno urbano.

El ejercicio del derecho a extinguir de forma unilateral el contrato es, precisamente, la herramienta diseñada por el legislador para terminar un arrendamiento pactado por tiempo indefinido ${ }^{65}$, de forma que, ejercitado por cualquiera de los interesados, en caso del arrendatario, sin necesidad de invocar una causa justificada, y en caso del arrendador, debiendo hacerlo bajo pena de nulidad ${ }^{66}$, se extinguirá el arrendamiento una vez transcurrido el plazo pactado o derivado de la ley. Las causas de extinción unilateral del contrato pueden ser ordinarias ${ }^{67}$ o extraordinarias, y las extraordinarias, a su vez, pueden

\footnotetext{
${ }^{65}$ Conforme al $\S 542$ del BGB, cada una de las partes contratantes puede extinguir unilateralmente el contrato de arrendamiento conforme a las reglas recogidas en el código, teniendo en cuenta que, si en el contrato se pactó una duración determinada, el arrendamiento terminará cuando finalice dicha duración, salvo que concurra una de las causas de extinción extraordinarias ( $\$ 575$ a BGB) o se prorrogue la duración del contrato.

${ }^{66} \mathrm{El} \S 573$ a BGB incluye una excepción a la necesaria concurrencia de una causa justificada y es que el arrendador viva en el mismo edificio que el arrendatario, y dicho edificio solo este compuesto por la vivienda habitada por el arrendatario y la suya propia, es decir, dos viviendas. Esta excepción se refiere también al supuesto de que arrendador y arrendatario compartan vivienda, salvo que, en cumplimiento de lo dispuesto en el $\S 549$ apartado $2^{\circ}$ número $2^{\circ}$ del $\mathrm{BGB}$, quede excluido de la normativa protectora.

${ }^{67}$ Las causas ordinarias para extinguir el contrato, conforme al $\S 573$ del BGB son: (i) que el arrendatario incumpla de forma culposa las obligaciones derivadas del contrato, siempre que no se trate de un incumplimiento irrelevante; (ii) que el arrendador necesite la vivienda para sí mismo, para un familiar o pariente, o para un conviviente, siempre que esa necesidad no la conociera con carácter previo a la celebración del contrato, pues en tal caso debería haber optado por un arrendamiento por tiempo definido, conforme al $§ 575$ BGB; y, (iii) que el arrendamiento vigente le impida una revalorización de la vivienda $\mathrm{y}$, como consecuencia, pérdidas importantes, siempre que su intención no sea arrendar nuevamente la vivienda para lograr una renta superior, pues lo prohíbe expresamente el $\S 573$ del BGB.
} 
estar sometidas a plazo de preaviso ${ }^{68} \mathrm{o} \mathrm{no}^{69}$. Para poder declarar unilateralmente la extinción del contrato, el arrendador deberá notificárselo por escrito al arrendatario, incluyendo expresamente la causa que justifica la extinción e informándole de la posibilidad de oponerse, así como de la forma y el plazo para hacerlo (§ 568 BGB). En caso de incumplimiento de la obligación del arrendador de exponer la causa justificada, la declaración será nula por falta de forma ${ }^{70}$.

Así pues, el legislador prevé distintas causas que legitiman al arrendador para emitir dicha declaración, siempre y cuando se trate de una de las causas enumeradas en la ley o de un supuesto asimilado a aquellas ${ }^{71}$. Además, la causa que se presente como justificación de la extinción del contrato debe ser grave o importante. Y, aun ante la efectiva concurrencia

\begin{abstract}
${ }^{68} \mathrm{~A}$ lo largo del articulado del BGB, se determinan supuestos en los que cabe extinguir unilateralmente el contrato por causa extraordinaria, pero este derecho queda sometido a un plazo de preaviso, en concreto, al mismo plazo que establecen el $\S 573$ y $§ 573$ a BGB para la extinción por causas ordinarias. Los supuestos son los siguientes: el $\S 540$ del BGB se refiere a la negativa del arrendador a consentir el subarriendo o cesión por parte del arrendatario a un tercero, que justifica que el arrendatario desista de forma extraordinaria, pero con sujeción a los plazos señalados. Este derecho de desistimiento decae si en la persona del tercero concurre una causa importante que justifique la negativa del arrendador. Otra causa se recoge en el § 555.e BGB que permite al arrendatario desistir del contrato si el arrendador le notifica que va a llevar a cabo obras de modernización en la vivienda; y en el § 561 BGB tras una elevación de la renta, aun a pesar de realizarse por los medios dispuestos para ello. Finalmente, para el caso de la subrogación mortis causa, el $\S 563$ BGB otorga el derecho de desistimiento al arrendador si en la o las personas que se subroguen en la posición del arrendatario fallecido concurre una causa importante que justifique que no desee continuar con el arrendamiento. A su vez, el $\S 563$ a BGB prevé, ante un arrendamiento compartido por varios arrendatarios, que, ante el fallecimiento de uno de ellos, continúe el arrendamiento con los sobrevivientes, salvo que en el plazo de un mes desde que tengan conocimiento del fallecimiento, desistan del contrato. De no existir las personas que según la norma tienen derecho a subrogarse en la posición del arrendatario, este derecho recaerá sobre su heredero. Tanto el heredero como el arrendador contarán con el plazo de un mes para desistir del contrato, bien desde el fallecimiento del arrendatario o desde la fecha en la que tengan constancia de que las personas con derecho a subrogarse hayan decidido no hacerlo $(\S 564$ BGB).
\end{abstract}

${ }^{69}$ De una lectura conjunta de los $\S \S 543$, disposición general, y $\S 569$, disposición específica referida al arrendamiento de vivienda, se extrae una regla general según la cual cualquiera de las partes podrá declarar unilateralmente la extinción del contrato sin sujeción a plazo alguno, siempre que medie una causa justificada para ello. El propio precepto define el concepto de "causa justificada" indicando que existirá cuando, considerando todas las circunstancias del caso concreto, sobre todo, un endeudamiento o incumplimiento, y ponderando los intereses de ambos, no sea razonable obligar a la parte afectada a continuar con el arrendamiento hasta que expire la duración pactada en el contrato o el plazo que establece la ley. Las causas concretas que enumera el precepto son: (1) respecto del arrendatario, si no le ha sido entregado el uso de la cosa arrendada en su totalidad o parcialmente, o si una vez entregada se le retira posteriormente y si de las características de la vivienda se deriva un riesgo grave de enfermar (2) en cuanto al arrendador, si el arrendatario amenaza con dañar considerablemente la cosa arrendada por un uso contrario a la diligencia debida o le cede el uso de la cosa a un tercero sin consentimiento del arrendador y la falta de pago de dos rentas consecutivas o de una cantidad considerable de dichas rentas, o la falta de pago en un periodo superior a esos dos meses consecutivos, si la cantidad debida equivale a la renta de dos meses; y (3) que cualquiera de las partes interrumpa el uso pacífico de la vivienda (Hausfrieden), de tal manera que, considerando las circunstancias del caso, los posibles incumplimientos que concurran y los intereses de cada parte, el mantenimiento del arrendamiento por la duración pactada o una plazo de preaviso marcado por la ley, no pueda razonablemente imponerse a la parte perjudicada.

${ }^{70}$ MEHLE, “\$542 Ende des Mietverhältnisses”, en beck-online.GROSSKOMMENTAR, (Schmidt, H.), 2021, Rn. 20.

${ }^{71}$ Otra vía para extinguir el contrato sería el mutuo disenso, admitido con base en el apartado $1^{\circ}$ del $\S 311$ del BGB (MEHLE, “\$542 Ende des Mietverhältnisses”, op.cit, Rn. 129). 
de una causa de tal gravedad o importancia, ya sea de las expresamente enumeradas o de una de similar contenido y entidad, el arrendatario dispone de una herramienta que sirve de barrera jurídica al efecto de la declaración de extinción unilateral. Se trata de la oposición fundada en el perjuicio grave (Härte $)^{72}$ que se derivaría para el arrendatario en caso de extinguirse el arrendamiento. De oponerse a la extinción, será el juzgado competente el que bareme los intereses concurrentes -de arrendador, de un lado, y arrendatario, del otro-, para determinar el de mayor necesidad ${ }^{73}$. Una vez ponderados los intereses, el arrendatario puede solicitar que el arrendamiento continúe por todo el tiempo que, a la vista de las circunstancias, sea razonable. Se justifica esta protección del arrendatario frente a la extinción del arrendamiento, según la propia Exposición de Motivos de la Ley de 1974 que lo introdujo definitivamente en el BGB, por cuanto que de la propia Constitución alemana (art. 2074) se deriva el deber del Estado Social de proteger al arrendatario cumplidor de sus obligaciones de una extinción arbitraria del arrendamiento de una vivienda que para él representa el centro de su misma existencia ${ }^{75}$.

Como ya se ha dicho, la duración indefinida es la regla general, pero no la única posibilidad permitida. Los principios configuradores de la reforma de 2001 y que debían informar la regulación contenida en el BGB eran la garantía de la propiedad, dentro de la función social a la que debe atender el propietario, la responsabilidad del arrendatario respecto de la cosa arrendada, y la cooperación entre arrendador y arrendatario. Lo que, en palabras del legislador alemán, también significa que en determinados casos no esté justificada la limitación de la autonomía de la voluntad de las partes ${ }^{76}$, para no provocar que para los arrendadores no fuera económicamente interesante o conveniente ofrecer sus viviendas en alquiler, a la vista de las medidas recogidas en la regulación ${ }^{77}$. Se debe esta

\footnotetext{
${ }^{72}$ Aclara el mismo § 574 BGB que una manifestación del perjuicio grave sería que no exista una vivienda alternativa con condiciones asumibles por el arrendatario. Sin embargo, no podrá oponerse si concurre alguna de las causas que justifican que el arrendador desista de forma extraordinaria y sin plazo de preaviso del contrato, pues dada la gravedad de las causas que suelen justificar este desistimiento extraordinario, ni siquiera una oposición por perjuicio grave puede invalidarlo.

${ }^{73}$ Un buen ejemplo de esta baremación se puede apreciar en la reciente sentencia de 25 de mayo de 2021 (ECLI:DE:LGBE:2021:0525.67S345.18.0A), en la que el Landesgericht de Berlín rechazó la evicción de la arrendataria de 89 años, aun concurriendo una causa justificada de necesidad del arrendador, valorando que la edad de la arrendataria unida a sus graves problemas de salud constituían un perjuicio suficientemente grave en caso de evicción para permitir su permanencia en la vivienda arrendada.
}

${ }^{74}$ Según el art. 20 GG: “(1) La República Federal de Alemania es un Estado federal democrático y social. (2) Todo poder del Estado emana del pueblo. Este poder es ejercido por el pueblo mediante elecciones y votaciones y por intermedio de órganos especiales de los poderes legislativo, ejecutivo y judicial. (3) El poder legislativo está sometido al orden constitucional; los poderes ejecutivo y judicial, a la ley y al Derecho. (4) Contra cualquiera que intente eliminar este orden todos los alemanes tienen el derecho de resistencia cuando no fuere posible otro recurso." Traducción disponible en: https://www.btgbestellservice.de/pdf/80206000.pdf [Última consulta: 14 julio 2021]

${ }^{75}$ Así se establece en la Exposición de Motivos (Drucksache 7/2011, p.7): "Bei der überragenden Bedeutung der Wohnung als Lebensmittelpunkt des menschlichen Daseins gebietet die Sozialstaatverpflichtung des Grundgesetzes (Artikel 20), den vertragstreuen Mieter vor willkürlichen Kündigungen und damit dem Verlust seiner Wohnung zu schützen”.

${ }^{76}$ Drucksache 14/4553, p. 34.

${ }^{77}$ Un ejemplo importante de que la regulación social del arrendamiento de vivienda podía limitar la inversión por parte de los propietarios y la oferta de vivienda es que no estaba permitido el arrendamiento 
aclaración al hecho de que, en los años anteriores, el sistema proteccionista (sociales Mietrecht) se centraba principalmente en medidas proteccionistas para el arrendatario, desatendiendo al arrendador, lo que debía evitarse en aras de conseguir aumentar la oferta.

Esta idea es la que ha llevado al legislador a introducir tipos dentro del arrendamiento de vivienda, y a tomar en consideración circunstancias particulares que requieren, para que el sistema funcione, apartarse de algunas normas generales y proteccionistas. Así, por ejemplo, se introducen los arrendamientos de duración determinada, aun a pesar de ser la regla general en el arrendamiento alemán, la del contrato de duración indefinida. Precisamente por tratarse de una excepción, los arrendamientos por duración determinada solamente serán válidos cuando respondan a circunstancias especiales y tasadas por el legislador en el $\S 575$ BGB, entre otros, la necesidad previsible del arrendador de usar la vivienda o el proyecto de reforma u obras, existente al tiempo de celebrar el contrato.

Dada la posibilidad que tiene el arrendatario de oponerse a la declaración del arrendador de extinguir el contrato, los propietarios han preferido no arrendar viviendas vacías, por prever las dificultades de desalojar al arrendatario, aun a pesar de concurrir circunstancias para ello. Así, el arrendador se enfrentaba a la complejidad de tener que demostrar la concurrencia de la necesidad o del proyecto de obra, y a desvirtuar las causas de oposición del arrendatario. A efectos de animar al propietario a arrendar las viviendas que, en otro caso, quedarían vacías, se introduce el arrendamiento de duración determinada, siempre que concurran las citadas causas, y se identifican también las normas específicas que no pueden resultar aplicables, puesto que impedirían el efecto que se quiere conseguir, que es la temporalidad determinada del arrendamiento y la certeza de que, llegado el vencimiento pactado, el arrendamiento se extingue, salvo pacto de prórroga. Incluso, si se dan las circunstancias, se admite también una extinción unilateral por causa extraordinaria sometida a los plazos legales ${ }^{78}$, pero se declaran no aplicables las normas que permiten al arrendatario extender la duración del arrendamiento, sin que se produzca indefensión para este a la vista del conocimiento previo que tiene de la fecha exacta de terminación del arrendamiento. Para reforzar la seguridad del arrendador, se introducen las normas procedimentales oportunas para desahuciar al arrendatario en caso de negativa de abandono de la vivienda. Un detalle importante que el legislador ha tenido en cuenta al establecer esta normativa, es que es posible que la causa que justificaba un contrato temporal desaparezca, en cuyo caso, y a la vista de la normativa general que impera en el

de duración determinada hasta 1982, año en el que se introduciría esta posibilidad cuando concurriera una causa justificada como la necesidad declarada del arrendador de ocuparla o bien que hubiera una importante obra proyectada. De esta manera, hasta tanto se produjera la causa la vivienda no permanecería vacía, sino que podía ofrecerse en arrendamiento.

${ }^{78}$ Un caso concreto es el recogido en el $\S 544$ BGB, que regula el contrato de arrendamiento de vivienda por más de 30 años, estableciendo que, llegado el término pactado, cualquiera de las partes tiene derecho a extinguir el contrato, salvo que el contrato sea vitalicio. La relevancia del ejercicio o no del derecho de extinguir el contrato, es que en su ausencia puede prorrogarse el contrato indefinidamente, si el arrendatario continúa usando la vivienda, y ni arrendador ni arrendatario manifiestan su voluntad en contra de la prórroga en el plazo de dos semanas ( $\$ 545$ BGB). No obstante, las partes pueden excluir esta posibilidad en el contrato, pues es una norma dispositiva (MEHLE, " $\$ 545$ Stillschweigende Verlängerung des Mietverhältnisses”, en beck-online.GROSSKOMMENTAR, (Schmidt, H.), 2021, Rn. 4). 
sistema alemán de indeterminación temporal del contrato, solamente podrá darse por terminado el mismo si concurren las causas generales de extinción del contrato.

3.1.B. La limitación a la elevación de la renta vigente el arrendamiento y el límite a la libre determinación inicial de la renta

En cuanto a los límites que impone el legislador alemán a la libertad de los contratantes de determinar la renta, se puede diferenciar entre la limitación a la determinación inicial de la renta al celebrar el contrato ( $\$ 556 \mathrm{~d}-\mathrm{g}$ BGB), que solamente se establece en determinados territorios que han sido previamente declarados como "mercados tensos de vivienda" en los que es especialmente difícil para potenciales arrendatarios de rentas bajas y medias encontrar una vivienda, y las normas para modificarla durante la vida del contrato $(\S 557-559 \mathrm{BGB})^{79}$.

El criterio base al que deben atenerse los contratantes es el de la ortsübliche Vergleichsmiete (renta comparativa del lugar), un concepto jurídico indeterminado que se delimita en el $\S 558$ del BGB, indicando que es aquel valor determinado por rentas habituales de ese municipio o un municipio comparable, para viviendas de similar estilo, tamaño, equipamiento, características, ubicación y eficiencia energética de los últimos cuatro años. Asimismo, en el $\S 558$ a BGB, se enumeran algunas herramientas que sirven para justificar la fijación de la renta comparativa, por ejemplo, los baremos de rentas de viviendas arrendadas o la base de datos de rentas.

Este criterio va a suponer un límite tanto al fijar la renta inicial de determinados arrendamientos, como para actualizar la renta posteriormente. Estando vigente el arrendamiento, los contratantes son libres de pactar una renta diferente a la inicialmente acordada (\$557 BGB), sin embargo, dado que en la mayoría de los supuestos será el arrendador el que pretenda modificarla al alza, este tipo de pacto es poco probable. También pueden elegir entre dos sistemas denominados, respectivamente, Staffelmiete (renta escalonada, $\S 557$ a) ${ }^{80}$, en la que se pactan distintas subidas de la renta para fechas futuras, perfectamente determinadas ${ }^{81}$, e Indexmiete (renta por índice, $\S 557$ b), en la que

\footnotetext{
${ }^{79}$ Cabe mencionar dos límites adicionales regulados en otros cuerpos legales: de un lado, el $\S 5$ del Wirtschaftsstrafgesetz (en adelante, WiStG) dispone que actúa de forma contraria al ordenamiento quien de forma dolosa o imprudente exija o acepte el pago o la promesa de pago de una renta inadecuada, y como tal define la renta comparativa incrementada en más de un 20 por ciento. Además, se exige que el arrendador haya aprovechado la escasez de vivienda y el esfuerzo del arrendatario para acceder a una vivienda, para asegurarse ese sobreprecio (BÖRSTINGHAUS, Miethöhe-Handbuch, München, C.H.Beck, 2a . ed, 2016, Capítulo 5, Rn. 20). Este pacto, que sería nulo conforme al $\S 134$ BGB, y el pago derivado de él, pueden ser rechazados por el arrendatario. A mayor abundamiento, se prevé la posibilidad de imponer una multa al arrendador. Finalmente, el código penal alemán prevé en su $\S 291$, que constituye delito que un arrendador consiga la promesa de pago de una renta que supere en un 50 por ciento la renta comparativa.

${ }^{80}$ BÖRSTINGHAUS, Miethöhe-Handbuch, op.cit., Capítulo 6, Rn. 23, menciona que también se puede pactar una Staffelmiete a la inversa, esto es, que la renta vaya disminuyendo en el futuro.

${ }^{81}$ Un dato interesante es que, en caso de pactar una renta escalonada, las partes pueden pactar que el arrendatario no pueda extinguir unilateralmente el contrato por un plazo de hasta cuatro años, pues no
} 
se pacta entre las partes que la renta sufrirá el aumento correspondiente a aplicarle el índice del coste de vida de todos los hogares privados en Alemania (hoy denominado Índice de Precios al Consumo - VPI) publicado por la Oficina Federal de Estadística.

En defecto de pacto, y a la vista de que el arrendador no puede extinguir el contrato si el arrendatario no acepta la modificación al alza de la renta, ni es causa de extinción la intención de celebrar un nuevo contrato para recibir una renta adecuada o superior, se permite que el arrendador equipare la renta inicialmente pactada a la renta que por comparación correspondería a una vivienda de las características y ubicación de la arrendada (la ya explicada ortsübliche Vergleichsmiete) ${ }^{82}$. De esta manera se evita que el arrendador sufra un perjuicio económico importante y que los propietarios no se planteen celebrar un contrato de arrendamiento indefinido que pasados unos años siga generando una renta inadecuada a un mercado que ha seguido evolucionando ${ }^{83}$. De negarse a aceptar la elevación de la renta, podrá suplirse la voluntad del arrendatario por el juez. Sin embargo, previendo que en un arrendamiento indefinido este derecho podría perjudicar gravemente al arrendatario que se embarcó en un arrendamiento probablemente valorando que la renta pactada era asumible, y se podría encontrar con una renta inabarcable tras la equiparación, se introduce un límite denominado Kappungsgrenze y que consiste en restringir durante tres años la subida de la renta a no más del 20 por ciento por encima de la renta inicialmente pactada ${ }^{84}$. Cabe destacar que la finalidad de la norma es limitar el derecho del arrendador a exigir la aceptación del arrendatario a elevar la renta, pero no impide que el arrendatario acepte incrementos que superen el límite

tendría sentido pactar una renta siguiendo este sistema, ni recurriría a él el arrendador, si existiera el temor de que el arrendatario extinga el contrato antes de que se produzcan los incrementos de la renta.

82 Una crítica muy interesante que aporta ARTZ, "BGB $\$ 558$ Mieterhöhung bis zur ortsüblichen Vergleichsmiete", en Münchener Kommentar zum BGB, Band 5, (dir. Henssler y Krüger), München, C.H.Beck, 8 a . ed., 2020, Rn. 3, pág. 534, es la unilateralidad del derecho a ajustar la renta a la renta comparativa, puesto que es únicamente el arrendador el que puede basarse en la adaptación de la renta a la que por comparación con la habitual correspondería, pero no a la inversa. Esto es, el arrendatario que, al calcular la renta comparativa, advierta que la misma es menor a la renta pactada no puede exigir que se disminuya la renta hasta equipararla. Sin embargo, aclara que la razón del derecho del arrendador a elevar la renta es precisamente por la prohibición a la que le somete la ley de desistir del contrato por no ser ya rentables las condiciones del arrendamiento ( $\$ 573$ apartado 1 BGB). Si no puede elevar la renta, ni tampoco desistir del contrato, entonces se produciría una congelación de la renta que, debido al sistema alemán, podría ser indefinida. Una situación muy similar a la que se produjo como consecuencia del TRLAU de 1964.

${ }^{83}$ Se argumentaba en la Exposición de Motivos de la Ley para el incremento de la oferta de viviendas en arrendamiento del 20 de diciembre de 1982 (Drucksache 9/2079, p. 7), que los arrendadores, al analizar la economicidad del arrendamiento de viviendas, la ponían en duda debido a las medidas proteccionistas existentes, lo que les había llevado a alejarse de ese sector para invertir en otros más económicos.

${ }^{84}$ Desde el punto de vista constitucional, la limitación a la que se somete al arrendador está justificada, por el balance que se hace de los intereses. Sin embargo, siguiendo a BÖRSTINGHAUS, Miethöhe-Handbuch, op.cit., Capítulo 11, Rn. 163, no podría justificarse constitucionalmente el límite del incremento hasta el 20 por ciento en tres años, si su aplicación deriva en pérdidas para el arrendador. En tal caso, señala el autor, se estaría vulnerando su derecho, recogido en el art. 14 del GG. Así mismo debe tenerse en cuenta que este porcentaje se reduce al 15 por ciento si la vivienda está situada en un municipio o parte del mismo especialmente afectado por la escasez de vivienda en condiciones adecuadas para el alquiler y declarado como tal por el gobierno del Land mediante reglamento por una duración máxima de cinco años. 
marcado ${ }^{85}$. En cualquier caso, de aplicarse cualquiera de los procesos de elevación de la renta, ya sea para equipararla a la renta comparativa del lugar, o por obras de mejora, que también justifican una modificación al alza de la renta (§ 559 BGB), el arrendatario tiene derecho a declarar la extinción del contrato, sin necesidad de justificar la extinción ( $\$ 561$ BGB).

La limitación a la determinación inicial de la renta (Mietpreisbremse) se introdujo en el BGB a través de la reforma llevada a cabo por medio del Mietrechtnovellierungsgesetz del 21 de abril de $2015^{86}$, que entró en vigor el 1 de junio de 2015 , si bien no es la primera vez que se limita la renta en el Derecho alemán ${ }^{87}$. A través de esta reforma se apoderó a los gobiernos de los distintos Länder, para determinar por medio de un reglamento, con carácter temporal ${ }^{88}$, los territorios que sufren de un "mercado tenso de vivienda" (angestrengter Wohnungsmarkt). El propio precepto ( $§ 556 \mathrm{~d}$ BGB) marca unas pautas para identificarlo: (i) cuando las rentas hayan aumentado considerablemente en comparación con la media del país; (ii) cuando la demanda de viviendas adecuadas para el arrendamiento aumente considerablemente en comparación con la media del país; (iii) que la población aumente, sin que se aumente el mercado de vivienda por medio de la construcción; (iv) que haya limitado espacio libre para una gran demanda.

Declarado en el territorio correspondiente la situación de "mercado tenso de vivienda", debidamente justificada bajo pena de nulidad ${ }^{89}$, resulta aplicable la limitación a todos aquellos contratos de arrendamiento que se celebren con posterioridad a la publicación del reglamento, excluyéndose expresamente los arrendamientos que recaigan sobre viviendas que se usen y arrienden por primera vez con posterioridad al 1 de octubre de 2014, así como viviendas íntegramente reformadas y que se arrienden por primera vez ( $\S$

\footnotetext{
${ }^{85}$ En efecto, BÖRSTINGHAUS, Miethöhe-Handbuch, op.cit., Capítulo 11, Rn. 163, destaca que el límite denominado Kappungsgrenze no constituye una prohibición legal, por lo que el arrendatario podría aceptar que se eleve la renta superando el límite.

${ }^{86}$ BGBI 2015, I, p. 610. No obstante, cabe mencionar que la regulación sobre la limitación de la renta en mercados tensos de vivienda sufrió una nueva reforma en el año 2019, a través del Mietrechtsanpassungsgesetz del 18 de diciembre de 2018, que entró en vigor el 1 de enero de 2019 (BGBI 2018 I p. 2648), que afectaba principalmente a la obligación precontractual del arrendador de informar al arrendatario de las razones que justifican el acogimiento a las excepciones del $\S 556 \mathrm{e} \mathrm{y} \mathrm{f} \mathrm{del} \mathrm{BGB} \mathrm{y} \mathrm{a} \mathrm{la}$ regulación sobre la necesidad de impugnar el sobreprecio pagado por el arrendatario para poder reclamarlo posteriormente.

${ }^{87}$ De hecho, BÖRSTINGHAUS, Miethöhe-Handbuch, op.cit., Capítulo 4, Rn. 2, recuerda que la regulación de la limitación de las rentas, introducida en 2015, no hace sino reproducir la regulación existente durante la Primera Guerra Mundial y que, de una manera u otra, ha ido resurgiendo por épocas.

${ }^{88}$ El reglamento debe ser promulgado antes del 31 de diciembre de 2020, pudiendo ser sometido a juicio ante los Juzgados civiles que tienen competencia para declarar su nulidad por falta de justificación, y tendrá una duración máxima de cinco años, sin posibilidad de prórroga.
}

89 Sentencia del Tribunal Supremo alemán (en adelante, BGH) de 17 de julio de 2019 (ECLI:DE:BGH:2019:170719UVIIIZR130.18.0). BÖRSTINGHAUS, Miethöhe-Handbuch, op.cit., Capítulo 11, Rn. 203, explica que los Juzgados civiles tienen el deber de comprobar si se han cumplido las exigencias que contiene el apoderamiento a los gobiernos de los Länder, con base en el art. 19 apartado $4^{\circ}$ del GG. Por su parte ARTZ, "Die Mietpreisbremse", $M D R$, 2015, pág. 553, mantiene que el arrendador puede, en caso de duda, acudir a los tribunales civiles para que se compruebe que el Land efectivamente tenía fundamento para dictar el reglamento. 
$556 \mathrm{f}$ BGB). De esta manera, se evita que potenciales inversores no deseen asumir el riesgo de la inversión de la nueva construcción o reforma de viviendas ante la futura limitación de la renta a la que quedarían sujetos los arrendamientos ${ }^{90}$.

La norma prohíbe que se establezca una renta superior a la renta comparativa habitual del lugar ${ }^{91}$, incrementada hasta en un 10 por ciento. No obstante, el arrendador tiene derecho a aplicar igual renta a la pactada en el contrato de arrendamiento anterior sobre la misma vivienda, si esta es superior a la que resultaría de aplicar la limitación, siempre que no se trate de una renta pactada en el año anterior a la extinción de dicho contrato ${ }^{92}$. Asimismo, cuenta con la posibilidad de añadir a la renta resultante de aplicar la limitación, el incremento que hubiera podido aplicar si hubiera llevado a cabo el proceso de elevación de la renta por obras de mejora ejecutadas en los últimos tres años en la vivienda, salvo que ya hubiera recurrido al proceso de elevación de la renta en el arrendamiento anterior (cfr. $\S \S 556$ e y f BGB) ${ }^{93}$.

\footnotetext{
${ }^{90}$ ARTZ, "BGB § 556f Ausnahmen”, en Münchener Kommentar zum BGB, Band 5, (dir. Henssler y Krüger), München, C.H.Beck, $8^{\mathrm{a}}$. ed., 2020, Rn. 1, págs. 486 y 487, indica que el sentido del precepto es evitar que los arrendadores opten por no invertir en la construcción de nuevas viviendas o en usarla por primera vez, debido a las limitaciones. FEINDL, " $\$ 556 \mathrm{~d}$ Zulässige Miethöhe bei Mietbeginn; Verordnungsermächtigung”, en beck-online.GROSSKOMMENTAR, (Schmidt, H.), 2021, Rn. 0, igualmente indica que estas medidas están ideadas para evitar que la limitación de rentas sea contraproducente y en vez de facilitar el acceso a la vivienda, lo complique, porque a los inversores no les interesa crear espacio para viviendas en estas circunstancias. Esta sería una consecuencia especialmente peligrosa y perjudicial, añade el autor (FEINDL, "§556f Ausnahmen”, en beck-online.GROSSKOMMENTAR, (Schmidt, H.), 2021, Rn. 0 ) puesto que en estas zonas las obras nuevas escasean y desincentivar a posibles inversores sería contrario a la propia finalidad de la norma. En iguales términos, BÖRSTINGHAUS, Miethöhe-Handbuch, op.cit., Capítulo 4, Rn. 12.
}

${ }^{91}$ Aun a pesar de tratarse de un concepto jurídico indeterminado, el $\S 558$ del BGB delimita el concepto ortsübliche Vergleichsmiete (renta comparativa), indicando que es aquel valor determinado por rentas habituales de ese municipio o un municipio comparable, para viviendas de similar estilo, tamaño, equipamiento, características, ubicación y efíciencia energética de los últimos cuatro años. Asimismo, en el $\S 558$ a BGB, se enumeran algunas herramientas que sirven para justificar la fijación de la renta comparativa, por ejemplo, los baremos de rentas de viviendas arrendadas o la base de datos de rentas.

${ }^{92}$ El legislador ha establecido la limitación del año, para evitar el posible fraude al que podrían recurrir los arrendadores, pactando la elevación de la renta con el anterior inquilino cuyo contrato esté por finalizar, asegurándose así la burla a la norma. En este sentido, ARTZ, "BGB § 556e Berücksichtigung der Vormiete oder einer durchgeführten Modernisierung", en Münchener Kommentar zum BGB, Band 5, (dir. Henssler y Krüger), München, C.H.Beck, $8^{\text {a }}$. ed., 2020, Rn. 12, p. 485; BÖRSTINGHAUS, Miethöhe-Handbuch, op.cit., Capítulo 4, Rn. 121. Aun así, FEINDL, "\$556e Berücksichtigung der Vormiete oder einer durchgeführten Modernisierung", en beck-online.GROSSKOMMENTAR, (Schmidt, H.), 2021, Rn. 0, sigue viendo posibilidades de fraude a la norma con esta excepción.

${ }^{93}$ Según FEINDL, “\$556e Berücksichtigung der Vormiete oder einer durchgeführten Modernisierung”, op.cit., Rn. 0, el fundamento detrás de esta excepción es evitar que el arrendador omita o desista de la realización de las obras de mejora o modernización razonables, por miedo a no conseguir rentabilizarlas con la renta o espere a realizarla una vez iniciado el mismo para poder recurrir al proceso de elevación de renta por modernización, con los inconvenientes que ello puede acarrear al arrendatario. 


\subsection{Otros tipos de arrendamientos que recaen sobre la vivienda: el § 549 BGB}

A continuación, se exponen los distintos tipos que detalla el legislador alemán en el parágrafo 549 BGB, su justificación para señalar determinadas normas que no resultan aplicables a ellos, y cuáles son estas normas.

\subsection{A. Arrendamiento temporal de vivienda}

El arrendamiento temporal de la vivienda, que no debe confundirse con los arrendamientos celebrados por duración determinada, a los que se refiere el art. 575 BGB, ya mencionados en el apartado anterior, se define doctrinalmente como aquel arrendamiento en el que la vivienda se va a destinar a un uso concreto que justifica la voluntad de las partes de celebrar un contrato de corta duración. La nota característica es que deben concurrir ambos elementos ${ }^{94}$ : el destino o finalidad que se dará a la vivienda y que subyace a la celebración del contrato y que supone un uso temporal de la misma ${ }^{95}$, sin embargo, aclara la doctrina que lo determinante no es tanto la duración en sí del contrato, sino que del destino pactado ${ }^{96}$ se infiera que la finalidad perseguida justifica un uso temporal de la vivienda ${ }^{97}$.

Teniendo en cuenta que el principal argumento para establecer como regla general que en contratos de duración indeterminada no puede el arrendador resolver el contrato sin una causa justificada para ello, es que la vivienda representa para el arrendatario el centro de su vida y que ha establecido en el tiempo que lleva habitándola unos lazos sociales y económicos en la zona, no cabe la aplicación de la normativa proteccionista relativa a la extinción del contrato en este supuesto, habida cuenta de que en tan corta duración no ha podido el arrendatario aun establecer ningún tipo de lazo, ni ha representado la vivienda

\footnotetext{
${ }^{94}$ En efecto, según BLANK, “\$549 BGB Auf Wohnraummietverhältnisse anwendbare Vorschriften”, en Mietrecht, (dir. Schmidt-Futterer), München, C.H. Beck, 14"a ed, 2019, Rn. 4, de no inferirse del contrato la concreta finalidad de celebrar un contrato temporal de arrendamiento, la indicación de que este debe durar solo unos meses, no será suficiente, tratándose entonces de un arrendamiento de duración determinada.

95 BLANK, “\$549 BGB Auf Wohnraummietverhältnisse anwendbare Vorschriften”, op.cit., Rn. 4; BIEBER, "BGB §549 Auf Wohnraummietverhältnisse anwendbare Vorschriften", en Münchener Kommentar zum BGB, Band 5, (dir. Henssler y Krüger), München, C.H.Beck, 8a . ed., 2020, Rn. 17.

${ }^{96}$ BIEBER, "BGB §549 Auf Wohnraummietverhältnisse anwendbare Vorschriften”, op.cit., Rn. 17.

${ }^{97}$ BIEBER, “BGB §549 Auf Wohnraummietverhältnisse anwendbare Vorschriften”, op.cit., Rn. 18, señala los siguientes ejemplos de arrendamientos temporales que permiten completar la definición: alojamiento temporal por trabajo, alojamiento temporal hasta tanto se encuentre la vivienda familiar, siempre y cuando sea previsible que la búsqueda no se extienda en el tiempo, estudiantes que arriendan la vivienda por un único semestre, con la intención de mudarse al finalizarlo. En cuanto a los arrendamientos de segundas residencias o vacacionales, deberá atenderse al caso concreto, puesto que un arrendamiento reiterado de la misma, hasta tal punto de que se convierta en un "segundo punto central de la vida del individuo" no constituiría un arrendamiento temporal (BRUNS, “\$549 Auf Wohnraummietverhältnisse anwendbare Vorschriften", op.cit., Rn. 14).
} 
para él el eje central de su vida, por lo que no sufre un perjuicio grave en caso de pérdida de la vivienda ${ }^{98}$.

\subsection{B. Arrendamiento de vivienda amueblada y compartida con el arrendador}

El segundo tipo a que se refiere es el arrendamiento de vivienda compartido por el arrendatario con el arrendador ${ }^{99}$, que haya sido mayoritariamente amueblada o equipada por el arrendador, siempre que el arrendatario no conviva a su vez con su familia o personas con las que comparta la gestión económica y personal de la vivienda con carácter permanente.

Pues bien, se justifica para este tipo la inaplicación de determinadas normas proteccionistas por producirse una invasión por parte del arrendatario en la esfera personal y habitacional del arrendador que, aun permitida, implica que deba prevalecer el derecho de propiedad de este ${ }^{100}$. Sin embargo, cede esta preferencia cuando la vivienda o habitación le haya sido cedida al arrendatario para que conviva con su familia en ella con vocación de permanencia ${ }^{101}$. Prevalece, por tanto, la protección de la familia al derecho de propiedad del arrendador, conforme a los dictados de la Constitución alemana (cfr. art. $6 \mathrm{GG})^{102}$. Cabe llamar la atención sobre la ampliación de esta excepción que, desde la reforma de 2001, se extiende a otras personas distintas de los familiares, con las que el arrendatario simplemente mantenga una relación de gestión económica y personal de la vivienda $^{103}$, siempre y cuando tenga carácter permanente. Es evidente que, en estos casos, no resulta aplicable el fundamento de la protección de la familia consagrada en la Constitución alemana. Entiende BRUNS ${ }^{104}$ que la aplicación de la normativa

\footnotetext{
${ }^{98}$ BRUNS, “§549 Auf Wohnraummietverhältnisse anwendbare Vorschriften”, op.cit., Rn. 13.

${ }^{99}$ La persona del arrendador no tiene que ser necesariamente coincidente con la del propietario de la vivienda, sino que también es constitutivo de este tipo el supuesto del subarrendador y el subarrendatario que comparten vivienda. En este sentido, BLANK, “\$549 BGB Auf Wohnraummietverhältnisse anwendbare Vorschriften”, op.cit., Rn. 6 y 7; BIEBER, "BGB §549 Auf Wohnraummietverhältnisse anwendbare Vorschriften", op.cit., Rn. 19.
}

${ }^{100}$ Se asemeja la posición del arrendatario en este supuesto a la del “invitado” (Gast), según BRUNS, “\$549 Auf Wohnraummietverhältnisse anwendbare Vorschriften”, op.cit., Rn. 23 y 24, por lo que se suaviza el criterio de que la vivienda representa para el arrendatario el centro de su vida, y se suaviza por tanto también su preferencia frente al derecho del propietario (o del arrendador).

101 Para que se entienda cumplido este requisito basta con que en el contrato se haya permitido que el arrendatario conviva con su familia en las estancias señaladas o que no haya oposición a dicha convivencia. No obstante, no se entiende cumplido este requisito cuando el arrendatario haya acogido a su familia en la vivienda sin consentimiento del arrendador, como explica BLANK, "§549 BGB Auf Wohnraummietverhältnisse anwendbare Vorschriften", op.cit., Rn. 13.

${ }^{102}$ Así lo justificaba el legislador en la Exposición de Motivos de la Ley de 1974 (Drucksache 7/2011, pág. 9), con referencia a la norma que servía de antecedente a la actual.

${ }^{103}$ En la Exposición de motivos de la Ley de Reforma de 2001 (Drucksache 14/4553, pág. 38) se enumeran los siguientes ejemplos para ilustrar a qué tipo de relaciones se refiere esta norma: relaciones de análoga afectividad a la marital, pero también cualesquiera otras relaciones de convivencia permanente, como, por ejemplo, personas de edad avanzada que deciden convivir, incluso otorgándose mutuamente poderes para actuar en nombre del otro.

${ }^{104}$ BRUNS, “\$549 Auf Wohnraummietverhältnisse anwendbare Vorschriften”, op.cit., Rn. 25. 
proteccionista en este caso se debe a la pluralidad de usuarios de la vivienda que conviven con el arrendatario. En cualquier caso, solamente se dará esta posibilidad de que el arrendatario conviva con otras personas cuando el arrendador lo haya consentido al celebrar el contrato, por lo que, a la vista del conocimiento previo que tiene el arrendador de que sí se van a aplicar todas las normas proteccionistas ${ }^{105}$, parece justificada la excepción.

La vivienda debe ser entendida en sentido amplio, puesto que se puede referir a una casa unifamiliar o a una casa que esté dividida y habitada por varias familias (Einfamilienhaus / Mehrfamilienhaus). En el primer supuesto, se daría el arrendamiento compartido cuando el arrendatario esté alojado en una habitación o varias de la casa del arrendador, mientras que, en el segundo supuesto, basta con que, a parte de la vivienda con salida propia del arrendatario, comparta la cocina y/o el baño con el arrendador. Por tanto, no se incluye solamente el supuesto de compartir la vivienda, en el sentido de que el arrendador se aloje en una habitación y el arrendatario en otra, sino que también aplicaría esta norma en caso de que el arrendatario viva fuera de la vivienda del arrendador, pero use zonas comunes tales como la cocina ${ }^{106}$. Si no se comparte ninguna estancia, pero ambos viven en el mismo bloque, no se dan los presupuestos del tipo ${ }^{107}$.

De la literalidad de la norma se deriva que uno de los requisitos es que la vivienda haya sido amueblada y equipada mayoritariamente por el arrendador, si bien lo determinante es que se haya pactado en el contrato la obligación del arrendador de equipar la vivienda o, al menos, que la mayor parte, esto es, más de la mitad del equipamiento y muebles deba aportarla el arrendador ${ }^{108}$. No obstante, debe predominar la voluntad de los contratantes, puesto que, siguiendo a BLANK ${ }^{109}$ en caso de que se hubiera pactado en el contrato la entrega de una vivienda amueblada, pero la voluntad de las partes hubiera sido entregar una vivienda vacía -que, además, es lo que se entrega-, entonces no puede ser constitutivo de este tipo.

\footnotetext{
105 No se aplican las normas proteccionistas, dice BRUNS, "§549 Auf Wohnraummietverhältnisse anwendbare Vorschriften", op.cit., Rn. 25, aun habiendo pactado en el contrato la posibilidad de que el arrendatario conviva con terceras personas o con su familia o cónyuge en la vivienda, en caso de que finalmente no lleguen a convivir con aquel. Será el hecho de la entrada a vivir en la vivienda por los terceros, lo que suponga la aplicación de la normativa protectora.

${ }^{106}$ No basta con que se usen determinadas habitaciones comunes de vez en cuando, sino que tiene que tratarse de un uso frecuente, como el de la cocina o el baño (BRUNS, "§549 Auf Wohnraummietverhältnisse anwendbare Vorschriften”, op.cit., Rn. 23).

107 BLANK, “\$549 BGB Auf Wohnraummietverhältnisse anwendbare Vorschriften”, op.cit., Rn. 9; BIEBER, “BGB §549 Auf Wohnraummietverhältnisse anwendbare Vorschriften”, op.cit., Rn. 20.

108 Según BIEBER, “BGB §549 Auf Wohnraummietverhältnisse anwendbare Vorschriften”, op.cit., Rn. 22 , la vivienda debe estar suficientemente equipada como para permitir su uso inmediato. A lo que añade BRUNS, “\$549 Auf Wohnraummietverhältnisse anwendbare Vorschriften”, op.cit., Rn. 24, que cuando la norma establece que debe predominar el equipamiento y muebles aportados por el arrendador, por tanto, en más de la mitad, se refiere al equipamiento en sí y no al valor de los muebles.
}

${ }^{109}$ BLANK, “\$549 BGB Auf Wohnraummietverhältnisse anwendbare Vorschriften”, op.cit., Rn. 12. 
3.2.C. Vivienda arrendada por una persona jurídica de Derecho público o privado que subarriende a una persona con urgente necesidad de acceder a una vivienda

Este tipo de arrendamiento de vivienda está orientado a personas con grandes dificultades para acceder a una vivienda en el mercado y, por tanto, con una necesidad apremiante de poder acceder a ella ${ }^{110}$. Se celebra un contrato de arrendamiento en el que el arrendatario es una persona jurídica de Derecho público o privado $^{111}$ cuyo objeto social sea el de prestar asistencia a las personas que se encuentren en la situación descrita. La persona jurídica pública o privada, entonces, les subarrienda la vivienda arrendada, advirtiéndoles de que la normativa proteccionista no es de aplicación.

De esta manera consigue el legislador que los arrendadores no se arriesguen a potenciales arrendatarios incumplidores o que tengan reticencias a arrendar sus viviendas para evitar problemas $^{112}$, sino que celebran el contrato con un intermediario que será el que subarriende a la persona necesitada. Dadas las circunstancias particulares que concurren en estos supuestos, la normativa proteccionista no resulta aplicable, un hecho del que deberá ser informado el subarrendatario en el momento de la celebración del contrato. Es posible la exclusión de la normativa proteccionista, precisamente, por cuanto que estos subarrendatarios quedan debidamente atendidos como consecuencia del objeto social de las personas jurídicas públicas o privadas subarrendadoras, que les obliga a proteger a las personas necesitadas a las que está orientada su actividad social ${ }^{113}$. La justificación, en este caso, es que existe un arrendatario principal que no va a destinar el inmueble a satisfacer su propia necesidad de vivienda, ni la de su familia, sino que va a subarrendarla a una persona que la necesita, en cumplimiento de su objeto social. El arrendador tiene la tranquilidad de que ha celebrado el contrato con un arrendatario principal que va a cumplir con las obligaciones pactadas, y que va a responder del cumplimiento, aunque sea una tercera persona la que habite la vivienda ${ }^{114}$. Otro atractivo para los arrendadores

\footnotetext{
${ }^{110}$ Se pueden enumerar, entre otros, los siguientes grupos de personas: personas de edad avanzada, familias monoparentales, familias numerosas, estudiantes, drogadictos, demandantes de asilo, refugiados, ex reclusos, etc. En este sentido, BLANK, " $\$ 549$ BGB Auf Wohnraummietverhältnisse anwendbare Vorschriften”, op.cit., Rn. 21; BRUNS, “\$549 Auf Wohnraummietverhältnisse anwendbare Vorschriften”, op.cit., Rn. 33.

${ }^{111}$ Es la Ley de 2001 la que extiende el ámbito personal a los subarrendadores que sean personas jurídicas de Derecho privado, puesto que la norma anterior se refería únicamente a personas jurídicas de Derecho público. Se argumenta que también las de Derecho privado pueden estar orientadas a prestar asistencia social, lo que justifica que se extienda a estas la excepción. Se citan en la doctrina (BLANK, "§549 BGB Auf Wohnraummietverhältnisse anwendbare Vorschriften", op.cit., Rn. 20) como ejemplos: la labor de la Iglesia Evangélica, Caritas, Cruz Roja, la Fundación de las Víctimas de la Guerra y Ejército, entre otros.

${ }^{112}$ La Exposición de Motivos pone como ejemplos posible arrendatarios que se encuentren en una situación de mendicidad o drogadicción.

${ }^{113}$ Efectivamente, así se confirma en la Exposición de Motivos de la Ley de 2001.

${ }^{114}$ Esta norma que, en principio, se había introducido en el BGB con carácter temporal (5 años), a través de la Ley de 17 de mayo de 1990, se prorrogó ya sin límite temporal, mediante la Ley de 21 de febrero de 1996, a la vista de los resultados conseguidos, esto es, que los arrendadores ofrecieran viviendas que, en otro caso, hubieran quedado vacías, por evitar los riesgos al arrendarles las viviendas a un intermediario de Derecho público. Explica la Exposición de Motivos de la última ley (Drucksache 13/1963, p. 5) que, a la vista de la escasez de vivienda, determinadas medidas debían prorrogarse, entre ellas, la estudiada aquí,
} 
es la mayor libertad de pacto en estos supuestos, precisamente por la exclusión de la normativa proteccionista.

Para los tres tipos anteriores no resultan aplicables las siguientes normas: (1) la limitación a la renta en mercados tensos de vivienda; (2) la protección frente a la elevación de la renta vigente el arrendamiento; (3) la protección del arrendatario frente a la extinción del arrendamiento y la oposición a la misma; y (4) el derecho de adquisición preferente en caso de establecimiento de una propiedad horizontal y venta de la vivienda arrendada.

\subsection{Arrendamiento de habitaciones en una residencia de estudiantes o jóvenes}

Ante todo, cabe aclarar, siguiendo a BLANK ${ }^{115}$ que no es que el legislador alemán haya considerado que los estudiantes universitarios y jóvenes merezcan menos protección que el restante grupo de personas demandantes de vivienda, sino que la idea que subyace a la regulación aparte de este tipo es que las residencias universitarias deben atender muchas solicitudes de estudiantes que, de otra manera, no podrían permitirse una vivienda arrendada por un particular. A la vista de que la oferta no puede atender a la totalidad de la demanda, se opta en estas residencias por el denominado "Rotationssystem" o "Rotationsprinzip", sistema o principio rotatorio, para atender a la demanda del mayor número posible de estudiantes. De esta manera se busca limitar la duración del arrendamiento, como máximo, por el tiempo que dure la carrera de cada estudiante, y cumplir con el principio del trato igualitario de los estudiantes, permitiendo, en la medida de lo posible, que puedan acceder a una residencia universitaria. No obstante, con anterioridad a la plasmación de este tipo de arrendamiento en el BGB, se consideraba como un arrendamiento de vivienda habitual, con la consecuencia de que se le aplicaba la normativa proteccionista en su totalidad, ya que según la interpretación de los tribunales no podía considerarse un arrendamiento de temporada, cuando superara la duración de un solo semestre ${ }^{116}$. Explica BRUNS ${ }^{117}$ que fueron las peticiones presentadas por las residencias universitarias las que propiciaron que se incluyera este tipo de arrendamiento de vivienda, al que no podía resultar aplicable la totalidad de la normativa proteccionista, permitiendo que el arrendamiento se extinguiera a instancias del arrendador, sin perjuicio del derecho del arrendatario de oponerse en caso de perjuicio grave.

asegurando que los arrendadores, confiando en la capacidad y voluntad de cumplir del intermediario, cediera sus viviendas en arrendamiento, para que finalmente fueran ocupadas por personas con necesidad de vivienda.

${ }^{115}$ BLANK, “\$549 BGB Auf Wohnraummietverhältnisse anwendbare Vorschriften”, op.cit., Rn. 33.

${ }^{116}$ Explica la Exposición de Motivos de la Ley de 20 de diciembre de 1982 (Drucksache 9/2079, p.11), que es la que introduce en el BGB este tipo de arrendamiento de vivienda, que los tribunales no consideraban los arrendamientos de viviendas en residencias universitarias por una duración que abarcara la totalidad de su carrera como un arrendamiento de temporada y, por tanto, debían someterse a la totalidad de la normativa proteccionista.

${ }^{117}$ BRUNS, “\$549 Auf Wohnraummietverhältnisse anwendbare Vorschriften”, op.cit., Rn. 40 y 41. 
Una vez explicada la justificación del legislador para establecer este tipo en la normativa del BGB, es preciso definir qué entiende por residencia de estudiantes, por un lado, y residencia de jóvenes, por otro. El primer grupo de personas se refiere a aquellos estudiantes de educación superior o formación profesional que se encuentren matriculados en una Universidad o Escuela Superior alemana, incluidos estudiantes visitantes. Mientras que en el caso de las residencias de jóvenes el grupo está compuesto por personas de las edades de 14 a 18 años ${ }^{118}$. No obstante, siguiendo la doctrina sentada en la sentencia del BGH de 13 de junio de 2012, no todas las residencias que acojan a estos grupos de personas cumplen los requisitos que permiten excluir la normativa proteccionista, sino que debe, en todo caso, aplicarse un criterio restrictivo al interpretarlo, de manera que es fundamental que la actividad de arrendamiento responda a un principio rotatorio que cumpla con el principio de trato igualitario entre los distintos demandantes de vivienda, basado en criterios abstractos y generales, que tengan en consideración las necesidades de todos los alumnos y que, además se deriven de la normativa o instrucciones propias de la residencia en cuestión ${ }^{119}$. No debe servir el $\S$ 549.III BGB, advierte el Tribunal, de base para que el arrendador despache a los arrendatarios que no le agraden, ni para lucrarse.

En este caso, las normas que no resultan de aplicación son también las relativas a la protección del arrendatario frente a la resolución del contrato por el arrendador y la regulación del precio de la vivienda, sin embargo, sí se mantienen las normas relativas a la cláusula social o de oposición a la extinción (\$ 574 BGB), siendo esta la razón por la que se ha recogido este tipo en un apartado independiente a los tres anteriores.

\subsection{E. El arrendamiento de viviendas a los empleados del arrendador}

Dentro de la regulación de los arrendamientos de vivienda, el subcapítulo $4^{\circ}$ del BGB dedica los $\S \S 576-576 . \mathrm{b}$, a aquellas viviendas arrendadas por los empresarios a sus empleados. Este tipo no se menciona entre los enumerados en el $\S 549$ BGB, por lo que se aplica la normativa general y proteccionista del arrendamiento de vivienda, pero a la vista de la relación laboral existente entre las partes se modifican parcialmente las normas referidas a la extinción del arrendamiento y a la oposición a la misma, cuando la relación laboral finalice.

\subsection{Conclusión sobre el Derecho alemán}

A la vista de lo expuesto, puede apreciarse una intención clara en el legislador alemán de identificar los distintos tipos o grupos dentro del arrendamiento de vivienda y determinar aquellas normas que son apropiadas para cada uno de ellos.

\footnotetext{
${ }^{118}$ BLANK, “§549 BGB Auf Wohnraummietverhältnisse anwendbare Vorschriften”, op.cit., Rn. 34).

119 Así se explica en la citada sentencia del BGH de 13 de junio de 2012 (Ref.: VIII ZR 92/11), que la residencia operada por el demandado no respondía al principio rotatorio, basado en los criterios abstractos generales que preservaran el trato igualitario a todos los estudiantes, por cuanto que en el contrato se incluía meramente una posibilidad de prórroga de un contrato celebrado por un año.
} 
El legislador alemán concibe la vivienda objeto del arrendamiento de vivienda habitual como el centro de la vida del individuo y, por ello, en algunos aspectos lo equipara al derecho del propietario sobre su vivienda, atribuyéndole similar protección. Se protege el derecho adquirido por el arrendatario y su permanencia en la vivienda, de tal manera que la protección aumenta proporcionalmente al tiempo que lleve habitando la vivienda. Esta conclusión es fácilmente contrastable: la regulación establece como regla general un contrato de duración indefinida que solo ante la concurrencia de causas importantes y justificadas podrá quedar extinguido a instancias del arrendador. Además, para el caso de que efectivamente se vaya a producir la extinción, habrán de respetarse unos plazos de preaviso suficientemente largos para facilitar al arrendatario la búsqueda de una nueva vivienda de características similares. A partir de cinco años de alojamiento en la vivienda arrendada, los plazos de preaviso se ven incrementados. Incluso, cuando la causa de extinción alegada por el arrendador es la necesidad propia o de un familiar de ocupar la vivienda, el arrendatario puede, con base en el art. 14 de la Constitución alemana, acudir a los tribunales para que se valore y determine en cuál de los contratantes concurre la necesidad mayor. A mayor abundamiento, quedará el arrendador obligado a ofrecerle al arrendatario, si dispone de ella, una vivienda de similares características a la arrendada. Se protegen, por ende, los lazos del arrendatario con la vivienda arrendada. A mayor duración, mayor protección.

Pero, igual que la permanencia en la vivienda arrendada y las relaciones que surgen como consecuencia de esta merecen la máxima protección que el derecho pueda ofrecer, no puede aplicarse por igual a todos los arrendamientos que puedan recaer sobre una vivienda, puesto que, en tal caso, se reduciría considerablemente la oferta de vivienda, debido a que no todos los potenciales arrendadores quieren o pueden atenerse a un régimen tan proteccionista.

Pues bien, se enumeran en el Derecho alemán diferentes causas, situaciones, intereses y motivaciones, tanto del arrendador como del arrendatario, que justifican la referencia a tipos de arrendamientos de vivienda diferenciados del arrendamiento de la vivienda habitual o, incluso, tratándose de la vivienda habitual, circunstancias que justifican un tratamiento distinto, como que se comparta la vivienda con el propietario. El establecimiento de distintos tipos con una regulación adecuada para cada uno de ellos, facilita que los arrendadores sigan invirtiendo en el sector y que otros arrendadores ofrezcan viviendas en arrendamiento que, en otras circunstancias, quedarían vacías por saber que tendrán necesidad de ocuparla, o reformarla o por cualquier otra razón.

\section{PROPUESTA DE INTRODUCCIÓN DE NUEVOS TIPOS DE ARRENDAMIENTOS DE VIVIENDA EN EL CÓDIGO CIVIL Y LÍNEAS GENERALES DE SU REGULACIÓN}

Por las razones que ya se han expuesto ampliamente en apartados anteriores, el sistema de arrendamientos urbanos vigente en España genera, entre otros, el problema de la incertidumbre, que debe ser remediado. Se propone para ello eliminar la actual distinción 
entre el arrendamiento de vivienda y el arrendamiento para uso distinto de vivienda. Como ya se ha puesto de manifiesto, no se trata, propiamente, de una contraposición entre el arrendamiento de vivienda habitual y el resto -lo que podría tener un sentido-, sino que la situación es considerablemente más confusa, por cuanto que dentro de los "arrendamientos para uso distinto del de vivienda" se agrupan figuras muy distintas y necesitadas de regulación diferenciada. Al margen del hecho de que, en todos los supuestos englobados en esta categoría, el juego del principio de libertad de pacto sea amplio, poco o nada tienen que ver los arrendamientos de espacios destinados a vivienda y los destinados a fines comerciales, industriales, o profesionales. Complica aún más la funcionalidad del sistema arrendaticio español el hecho de que exista un régimen común, de aplicación supletoria o directa, según los casos, a arrendamientos que recaen sobre viviendas.

Pues bien, a la vista de la falta de adecuación tanto de la tipología existente en nuestro ordenamiento como de la regulación contenida en el CC y la LAU, se propone regular nuevamente todos los arrendamientos que tienen por objeto una vivienda, derogando la ley especial y devolviendo la regulación de los arrendamientos de vivienda al CC, en el que, con inspiración en la metodología alemana, se prevean disposiciones generales aplicables a todos los tipos de arrendamiento de vivienda para, a continuación, diferenciar entre los distintos tipos que el legislador decida regular atendiendo a su aparición y arraigo en la práctica y estableciendo para estos, en función de sus particularidades, solamente aquellas normas que sean estrictamente necesarias para atenderlas.

Este nuevo planteamiento supone el abandono, siquiera parcial, de la tradicional distinción, que ya acogió el Derecho codificado, entre arrendamientos urbanos y arrendamientos rústicos, que dejaría de ser central en el ámbito de los arrendamientos de inmuebles.

A continuación, se exponen cada una de las propuestas por separado, justificando su conveniencia, y estableciendo los rasgos generales de la regulación.

1.- Propuesta de regulación de los tipos de arrendamiento de vivienda en el Código Civil

La conveniencia de que los distintos tipos de arrendamiento de vivienda queden regulados en el CC empieza por la necesidad de modificar el régimen común que ha quedado anticuado y resulta inadecuado a la realidad social y económica actual, en concreto, respecto de la dicotomía: arrendamientos urbanos y arrendamientos rústicos. A través de la introducción en el CC de unas disposiciones generales aplicables a los arrendamientos de vivienda y disposiciones especiales para cada tipo de arrendamiento, pero solamente en función de sus particularidades, se consigue clarificar la estructura y, a la vez, se permite una modificación sencilla, de ser necesaria, introduciendo nuevos tipos que aparezcan en la práctica y que no tengan cabida en los tipos que ya estarían recogidos en el CC. 
El hecho de que determinadas normas, necesariamente, deban tener naturaleza imperativa no debe ser impedimento para elegir el CC como sede normativa para los arrendamientos de vivienda. De hecho, desde su promulgación son muchas las normas imperativas que se han recogido entre su articulado.

Por otra parte, se conseguiría cumplir con un objetivo muy recomendable como es evitar la dispersión normativa y el uso innecesario de las leyes especiales, vaciando de contenido nuestro Código Civil. Sobre todo, en sede arrendaticia, la regulación pendular que caracteriza a las leyes especiales de arrendamientos urbanos ha mostrado la necesidad de buscar cierta estabilidad normativa, una estabilidad que podría aportar la regulación en el Código civil, menos expuesto, quizás, a los vaivenes políticos. Este objetivo final interesa no solo a los arrendatarios, sino, en general, a todo el mercado de vivienda.

2.- Propuesta de nuevos tipos de arrendamientos de vivienda y rasgos generales de su regulación

La primera y más importante clasificación que debe realizarse es la del arrendamiento de la vivienda habitual, de un lado, y el arrendamiento de la vivienda no habitual, de otra. Evidentemente, si la clasificación se limitara a diferenciar entre estos dos tipos, a la vista del contenido tan diverso y amplio que podrían abarcar, no se estaría consiguiendo facilitar, mejorar ni adecuar el régimen jurídico de los arrendamientos de vivienda. Por tanto, para evitar caer en los mismos errores repetidos hasta la actualidad, es necesario precisar perfectamente el contenido de cada grupo y dividirlo en subgrupos, estableciendo una regulación adecuada para cada una de las particularidades que presenten.

La estructura que se propone es la siguiente:

1. Disposiciones generales aplicables a los arrendamientos de vivienda.

2. Arrendamiento de vivienda habitual.

a. Un solo arrendatario o un arrendatario junto a su cónyuge o persona con análoga relación de afectividad o relación convivencial y/o hijos.

b. Varios coarrendatarios como titulares de un único contrato sobre la totalidad de la vivienda.

c. Por habitaciones, con derecho a usar zonas comunes.

i. Arrendatarios que no comparten con el propietario.

ii. Arrendatarios que comparten con el propietario.

d. Co-housing/Co-living/Cooperativas de cesión de uso.

3. Arrendamiento de una vivienda no habitual. 
a. Por finalidad sometido a término incierto.

b. Por temporada.

c. Para fines turísticos.

En el segundo grupo sería conveniente (debido a la diferente finalidad de cada tipo) regular la pluralidad de arrendatarios. Asimismo, deberá valorarse la conveniencia de introducir normas específicas en aquellos casos en que la relación arrendaticia se celebre entre un empresario y un consumidor, tanto respecto de los arrendamientos de la vivienda habitual como no habitual.

Con carácter previo a la exposición y justificación de cada tipo y de los rasgos generales de su regulación, cabe indicar cuáles serían las disposiciones generales aplicables a todos ellos. Un aspecto importante será establecer la naturaleza imperativa o dispositiva de las disposiciones generales. Por ejemplo, respecto del deber de información deberá señalarse su carácter imperativo para todos los tipos, dada la importancia de este derecho del arrendatario. En cualquier caso, cabe recordar que, dentro del $\mathrm{CC}$, a falta de previsión contraria, las normas se consideran dispositivas.

Así, en el primer capítulo ${ }^{120}$ dirigido a establecer las disposiciones generales aplicables a todos los tipos, se recogería el concepto de arrendamiento de vivienda, que, posteriormente, puede adaptarse según las particularidades de cada tipo. Es necesario establecer un concepto para que quede claro el ámbito de aplicación de la normativa, pero también para evitar que espacios que no reúnan los requisitos mínimos exigibles se cedan con esa finalidad. El concepto general no es incompatible, como se ha dicho, con que se adapte, limite o amplíe según el tipo del que se trate.

Normas tales como las obligaciones y los derechos de las partes se indicarían con carácter general, siendo fundamental regular el deber de información que recaerá sobre el arrendador acerca de las particularidades del tipo de arrendamiento celebrado y los derechos y obligaciones del arrendatario. Precisamente por existir varios tipos de arrendamientos de vivienda, es necesario que tanto arrendador como arrendatario conozcan el diferente régimen aplicable a cada uno, pues la información adecuada favorecerá la elección del tipo que mejor se adapte a las necesidades de cada uno y permitirá evitar la litigiosidad entre las partes. Buena prueba de ello es el estudiado sistema alemán, en el que existe un deber general de información, que se reitera ante cada una de las normas que recogen derechos del arrendatario. Es importante aclarar que este deber de información no se limitará a los supuestos de arrendamientos celebrados con consumidores, puesto que, como se ha dicho, cuantos más tipos y subtipos haya, más importante es el derecho y deber de información. Así, cabe recordar que, en la mayoría de los supuestos, el arrendamiento de vivienda se celebra entre particulares. Finalmente,

${ }^{120}$ Nótese que la estructura elegida no concuerda actualmente con la propia del título dedicado al arrendamiento en el CC, pero se expone en capítulo y secciones para facilitar la exposición, debiendo revisarse para una posible inclusión del régimen propuesto en el CC. 
se expondrá el régimen jurídico aplicable, explicando la sistemática empleada para regular los arrendamientos de vivienda, y se advertirá de las consecuencias del incumplimiento de aquellas normas que tengan carácter imperativo.

El capítulo segundo dedicado al arrendamiento de la vivienda habitual se dividiría en cuatro secciones (vid. ud supra) cuyo contenido se expone a continuación.

La primera sección recogería la regulación del arrendamiento de vivienda habitual celebrado por un solo arrendatario, o por este y su cónyuge o persona con la que mantenga una análoga relación de afectividad o una relación convivencial, y/o con sus hijos. Se regularía en esta sección la normativa general del arrendamiento de vivienda habitual para la que será necesario mantener las normas proteccionistas propias de este tipo, algunas de ellas en similares términos a las normas de la LAU, pero con una importante diferencia: el principio que debe presidir la regulación del arrendamiento de la vivienda habitual es esa idea, que ha recogido sabiamente el Derecho alemán, del lazo del arrendatario con la vivienda.

Actualmente, la regulación está centrada en proteger al arrendatario de vivienda habitual por una duración mínima de cinco años, sin que se prevea por el legislador que, precisamente el uso de la vivienda durante cinco años puede suponer para el arrendatario la creación de unos lazos tanto con la vivienda arrendada como con el entorno, habiendo servido dicha vivienda como el centro de la vida del individuo. Pues bien, mientras que el legislador alemán entiende que el estado creado como consecuencia del uso continuado de su derecho merece protección, en el Derecho arrendaticio español el arrendatario queda desprotegido una vez agotada la duración mínima derivada del sistema de prórrogas.

Es por ello por lo que, en aras de brindarle la debida protección al arrendatario, es necesario establecer una regulación proteccionista que alcance, no solo a la duración mínima, sino que tenga en cuenta el lazo creado entre arrendatario y vivienda arrendada. Para lograrlo, la regulación no debe estar presidida por la idea del sistema de prórrogas, ni de la duración mínima, sino, por el contrario, estableciendo, como regla general, un contrato indefinido que beneficie tanto al arrendador como al arrendatario, lo que se logrará con una enumeración detallada de las causas que permiten la extinción del contrato por cualquier de las partes y su oposición en caso de que la misma sea injusta o suponga un perjuicio grave para alguna de las partes. Nótese que no por ser un contrato indefinido supone que el arrendador o el arrendatario no podrán extinguir el contrato. Para evitar que los interesados, sobre todo los arrendadores, sientan reticencia a arrendar sus viviendas por estar sujeto este tipo a un sistema de duración indefinida, será sumamente importante regular con mucho detalle las causas de extinción y oposición a la misma.

Aunque es opinión común que el arrendamiento indefinido en España se percibe con prevención o cautela, esta opinión está fundamentada sobre el ejemplo práctico del TRLAU de 1964 que tuvo graves consecuencias para muchos arrendadores por la perpetuación de los contratos de arrendamiento a través de la llamada prórroga forzosa y 
la congelación de las rentas. Sin embargo, existen otros ejemplos en nuestro sistema, previos a dicho texto refundido, que ya recogían esta posibilidad y, sobre todo, múltiples regulaciones exitosas en nuestros países vecinos, como Alemania. A mayor abundamiento, algunos autores ya han propuesto regular contratos de duración indefinida a la vista de sus ventajas ${ }^{121}$.

Es importante proteger la vinculación del sujeto con la vivienda, sabiendo también el arrendador que esto es así. Pero, precisamente por esa vinculación con la vivienda, y a la vista de que aumenta la protección que recibe el arrendatario, también debe, proporcionalmente, aumentar su participación en los gastos relacionados con la vivienda. A mayor similitud del derecho del arrendatario a un derecho de propiedad, mayor similitud a las obligaciones derivadas de la propiedad de la vivienda.

La sección segunda recogería las particularidades derivadas de la pluralidad de arrendatarios titulares en el contrato de arrendamiento sobre la totalidad de la vivienda arrendada. Principalmente, deberá establecerse el tipo de obligación que deriva del contrato para cada uno de los coarrendatarios, así como las reglas que disciplinan la relación entre ellos. Por otra parte, cabe establecer un sistema específico para el caso del desistimiento, abandono o fallecimiento de cualquiera de los coarrendatarios y las reglas de subrogación inter vivos y mortis causa.

La sección tercera referida al arrendamiento por habitaciones con derecho a usar zonas comunes, se diferencia del anterior por cuanto que cada arrendatario celebra un contrato independiente, persiguiendo, en todo caso, destinar la habitación a vivienda habitual. Es evidente que el arrendatario de una habitación también es merecedor de protección, pero también que los instrumentos de protección deben ser distintos. Así, por ejemplo, puede tener sentido el derecho de adquisición preferente en el arrendamiento de la vivienda habitual, pero no lo tendrá en el arrendamiento de una habitación. Por otra parte, no puede ignorarse el hecho de que cada uno de los arrendatarios tiene un contrato independiente y diferente al de los demás. Ello llevará a contratos de duración diversa y posiblemente una rotación más o menos continua de arrendatarios en la vivienda.

Dentro de esta sección parece recomendable diferenciar según que el o los arrendatarios que arrienden habitaciones de una vivienda la compartan con otros arrendatarios o bien con el propietario de aquella. Habida cuenta de las particularidades del primer supuesto y el segundo, parece justificado un tratamiento separado.

La sección cuarta establecería la normativa propia para las distintas fórmulas existentes en España del denominado co-living o co-housing que, entre otras, se materializa en nuestro país a través de la figura de la cooperativa de viviendas, en la que la cooperativa mantiene la propiedad de las viviendas, cediendo el uso de las mismas a los miembros de

121 MOLINA ROIG, E., Una nueva regulación para los arrendamientos de vivienda en un contexto europeo, Valencia, Tirant lo Blanch, 2018, pág. 702; QUICIOS MOLINA, S., "Capítulo II. De la duración del arrendamiento", en Propuesta de Código Civil, (Asociación de Profesores de Derecho Civil), Madrid, Tecnos, 2018, pág. 718. 
dicha cooperativa. Aunque la ley española y las distintas legislaciones autonómicas prevén la creación de este concreto modelo de cooperativa, no se refiere al régimen de cesión de uso o la relación que surge entre la cooperativa arrendadora y sus miembros arrendatarios. Aspectos tales como la normativa aplicable para lo no dispuesto en los estatutos o el juego de la autonomía de la voluntad quedarían regulados en esta sección.

El siguiente capítulo se dedicaría a aquellos arrendamientos que recaen sobre una vivienda pero que no cuentan con el elemento de la habitualidad y, por ende, no requieren ni merecen el mismo grado de protección.

La primera sección de este capítulo se dedicaría al arrendamiento de vivienda no habitual por finalidad sometida a un término incierto. Hay que tener en cuenta que, en ocasiones, el arrendatario persigue únicamente el uso de la vivienda con carácter transitorio, por ejemplo, durante un curso académico o mientras termina la reforma del inmueble que se adquiere en propiedad. En estos supuestos, el consentimiento de las partes estaría referido a una cesión que se produce por un tiempo que, aunque sea incierto o no se pueda precisar una fecha, si esté acotada por la finalidad perseguida, que no es la de la permanencia en la vivienda.

El arrendamiento por temporada sería el objeto de regulación de la sección segunda, que deberá regular el arrendamiento por temporada única, aunque habría que considerar la oportunidad de introducir o no normas sobre el arrendamiento por varias temporadas, teniendo en cuenta la existencia de la Ley 4/2012, de 6 de julio, de contratos de aprovechamiento por turno de bienes de uso turístico, de adquisición de productos vacacionales de larga duración, de reventa y de intercambio y normas tributarias, y su ámbito de aplicación.

Finalmente, acabaría este capítulo con la regulación del arrendamiento de vivienda con fines turísticos, en la sección tercera.

\section{CONCLUSIONES}

Primera. Actualmente, la legislación española de arrendamientos se refiere a tres tipos de arrendamiento que pueden recaer sobre una vivienda: el arrendamiento de vivienda habitual que, si reúne los requisitos del art. 2 LAU, queda sujeto a una regulación proteccionista e imperativa; el arrendamiento de temporada, mencionado en el art. $3 \mathrm{LAU}$, y al que se aplica la normativa contenida en el Título III LAU, basada en la autonomía de la voluntad de las partes y orientada a espacios dedicados a ejercitar actividades empresariales; y el arrendamiento de vivienda turística, a que se refiere el art. 5 LAU a los efectos de su inclusión o exclusión del ámbito de aplicación de la LAU en función de la existencia de una normativa sectorial turística en la Comunidad Autónoma de la que se trate.

Segunda. La legislación arrendaticia no es adecuada para responder a las particularidades que diferencian a cada uno de los arrendamientos que pueden recaer sobre una vivienda. 
Tampoco es completa, ya que no contempla o engloba todas las modalidades convivenciales que pueden concurrir.

Tercera. A la vista de las estadísticas y datos, así como la litigiosidad que manifiesta la jurisprudencia de las audiencias provinciales, es evidente que la tipología existente no se corresponde con la realidad sociológica de nuestro país, que demanda otros tipos apropiados a las nuevas modalidades convivenciales.

Cuarta. El arrendamiento de la vivienda habitual que regula la LAU es un arrendamiento celebrado por un solo arrendatario y sobre la totalidad de la vivienda, sin perjuicio de que conviva con sus familiares, cónyuge o persona con análoga relación de afectividad y/o sus hijos dependientes, siendo estos los únicos a los que hace referencia la normativa. No se regulan las particularidades derivadas de una pluralidad de arrendatarios, ni se hace referencia al alquiler por habitaciones con derecho a usar zonas comunes.

Quinta. Han sido las audiencias provinciales las que, interpretando la legislación vigente $\mathrm{y}$ analizando las circunstancias concurrentes, han determinado, respecto del arrendamiento compartido por varios arrendatarios, si las obligaciones contraídas a falta de pacto son solidarias; $y$, en cuanto al arrendamiento por habitaciones, si se reúnen los requisitos del art. 2 LAU para poder aplicar la normativa proteccionista, o si debían considerarse arrendamientos para uso distinto de vivienda, o excluirlos del ámbito de aplicación de la LAU.

Sexta. La normativa que debe aplicarse al arrendamiento de la vivienda no habitual y el arrendamiento turístico está, en realidad, diseñada y orientada a atender a los problemas jurídicos propios de un arrendamiento que tenga por objeto un uso empresarial o bien un régimen común, creado en 1889 para ser comprensivo de todo tipo de arrendamientos y, por tanto, poco o nada adecuado para atender a las particularidades propias, en el caso del arrendamiento de vivienda turística, de un arrendamiento que ni siquiera existía en la época en la que se promulgó.

Séptima. En el Derecho alemán se establece una regulación especialmente proteccionista del arrendamiento de la vivienda habitual por representar esta el centro vital del individuo, asentándose y estableciendo relaciones personales, familiares y económicas con su entorno. La protección es mayor cuanto mayor es la permanencia en la vivienda arrendada, garantizándose el derecho y situación adquiridos por el arrendatario. Se basa esta protección en la equiparación que hace el Tribunal Constitucional alemán del derecho de propiedad garantizado por el art. 14 de la Constitución alemana, al derecho del arrendatario. Tanto es así que aun cuando concurra una causa justificada basada en la propia necesidad del arrendador de ocupar la vivienda arrendada, el arrendatario puede oponerse a la extinción del contrato alegando el perjuicio grave que derivaría de ello, debiendo los tribunales decidir, con base en la prueba practicada, cuál sea la mayor de las necesidades. 
Octava. La regulación del arrendamiento de vivienda, en el Derecho alemán, se contiene en el BGB, estableciendo una regulación general para todos los arrendamientos, una específica para el arrendamiento de vivienda, y particularidades para distintos tipos de arrendamiento que recaen sobre una vivienda, pero a los que, por sus características, no se debe aplicar la normativa proteccionista en su totalidad. Se consigue de esta manera favorecer la inversión de los potenciales arrendadores en el sector del arrendamiento de viviendas, ya sea para celebrar arrendamientos de duración indefinida, los excepcionales de duración determinada o aquellos otros a los que por sus particularidades no están sometidos a todo el régimen proteccionista.

Novena. La propuesta que se recoge en este artículo es la de establecer una regulación completa y adecuada, que ofrezca estabilidad, lejos de los vaivenes políticos y del carácter pendular de la legislación especial, a través de la derogación de la LAU y la introducción en el CC de disposiciones generales aplicables a todos los arrendamientos que tengan por objeto una vivienda, diferenciando a continuación aquellos tipos que por sus particularidades requieran apartarse de las normas generales. Asimismo, se propone eliminar la dicotomía: arrendamientos urbanos y arrendamientos rústicos, por no corresponderse, en la actualidad, a los grandes grupos que por sus particularidades requieren de regulaciones distintas: arrendamientos que tengan por objeto una vivienda y arrendamientos que tengan por objeto espacios destinados a fines empresariales o profesionales.

Décima. En concreto, los tipos que se proponen, siempre sin perjuicio de la posibilidad de ampliarlos, son, principalmente dos: el arrendamiento de vivienda habitual y el arrendamiento de vivienda no habitual, ambos completados por diversos subtipos. Concretamente, el arrendamiento de vivienda habitual, con una regulación proteccionista, imperativa y completa, centrada en los lazos creados entre el arrendatario y la vivienda arrendada, la duración del arrendamiento y estableciendo suficientes causas justificadas de extinción del arrendamiento; el arrendamiento de vivienda habitual con pluralidad de arrendatarios, regulando el régimen interno entre los coarrendatarios y el tipo de obligación que se genera entre arrendador y coarrendatarios, así como las situaciones de desistimiento, abandono y subrogación de uno de los arrendatarios; el arrendamiento de vivienda habitual por habitaciones, estableciendo las condiciones mínimas de las habitaciones de uso individual y las zonas comunes y el consentimiento de los arrendatarios en caso de cambio de arrendatario; el arrendamiento de vivienda no habitual en el que prima la autonomía de la voluntad. Dentro de este tipo, se diferencian tres tipos: el primero, el arrendamiento de vivienda no habitual por finalidad, en el que se celebra un arrendamiento sometido a término incierto hasta tanto se cumpla la finalidad perseguida -distinta de la permanencia en la vivienda- y en el que no es necesario establecer una duración específica, pero se puede pactar una duración máxima; el arrendamiento de temporada y, finalmente, y aunque pudiera subsumirse en el tipo del arrendamiento de vivienda no habitual por finalidad, se propone una regulación diferente para el arrendamiento de viviendas turísticas habida cuenta de su especialidad. 


\section{BIBLIOGRAFÍA}

ARAGONESES ALONSO, P. y PASCUAL NIETO, G., "La vigente ley de arrendamientos y nuestro Derecho Histórico", Anuario de Derecho Civil, vol.9, núm. 1, 1956, págs. 33-84.

ARTZ, "BGB § 556e Berücksichtigung der Vormiete oder einer durchgeführten Modernisierung”, en Münchener Kommentar zum BGB, Band 5, (dir. Henssler y Krüger), München, C.H.Beck, $8^{\text {a }}$. ed., 2020, Rn. 1-18.

- "BGB § 556f Ausnahmen”, en Münchener Kommentar zum BGB, Band 5, (dir. Henssler y Krüger), München, C.H.Beck, 8a . ed., 2020, Rn. 1-7.

- "BGB §558 Mieterhöhung bis zur ortsüblichen Vergleichsmiete", en Münchener Kommentar zum BGB, Band 5, (dir. Henssler y Krüger), München, C.H.Beck, $8^{\mathrm{a}}$. ed., 2020, Rn. 1-68.

ARTZ, “Die Mietpreisbremse”, MDR, 2015, págs. 549-553.

AVILÉS GARCÍA, J., "Política de acceso a la vivienda, arrendamiento vigilado y libertad de mercado en la nueva LAU”, Revista de Derecho Patrimonial, núm. 34/2014, págs. 49-78.

BERCOVITZ RODRÍGUEZ-CANO, R., “Artículo 4.3. Régimen aplicable”, en Comentarios a la Ley de Arrendamientos Urbanos, (coord. Bercovitz Rodríguez-

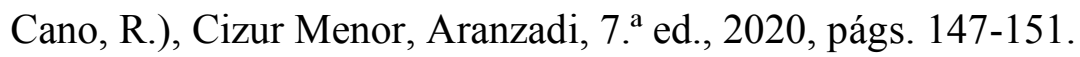

BIEBER, "BGB §549 Auf Wohnraummietverhältnisse anwendbare Vorschriften”, en Münchener Kommentar zum BGB, Band 5, (dir. Henssler y Krüger), München, C.H.Beck, $8^{\text {a }}$. ed., 2020, Rn. 1-37.

BLANK, “\$549 BGB Auf Wohnraummietverhältnisse anwendbare Vorschriften”, en Mietrecht, (dir. Schmidt-Futterer), München, C.H. Beck, 14ª ed, 2019, Rn. 1-49.

- “Vorbemerkung zu $\$ 535$ BGB”, en Mietrecht, (dir. Schmidt-Futterer), München, C.H. Beck, 14 a . ed, 2019, Rn. 1-427.

BÖRSTINGHAUS, Miethöhe-Handbuch, München, C.H.Beck, 2ª ed, 2016.

BOTELLO HERMOSA, J.M., "El contrato de arrendamiento de habitación: la problemática de su regulación. ¿Ley de Arrendamientos Urbanos o Código Civil?", Revista Crítica de Derecho Inmobiliario, núm. 754, 2016, págs. 10001038.

BRUNS, “§549 Auf Wohnraummietverhältnisse anwendbare Vorschriften”, en BeckOK Mietrecht, (dir. Schach, Schultz y Schüller), 2021, Rn. 1-51. 
CARRASCO PERERA, A., “Artículo 1137”, en Comentarios al Código Civil, Tomo VI, (coord. Bercovitz Rodríguez-Cano, R.), Valencia, Tirant lo Blanch, 2013, págs. 8361-8367.

FEINDL, “\$556d Zulässige Miethöhe bei Mietbeginn; Verordnungsermächtigung”, en beck-online.GROSSKOMMENTAR, (Schmidt, H.), 2021, Rn. 0-99.

- "\$556e Berücksichtigung der Vormiete oder einer durchgeführten Modernisierung", en beck-online.GROSSKOMMENTAR, (Schmidt, H.), 2021, Rn. 0-67.

- “\$556f Ausnahmen”, en beck-online.GROSSKOMMENTAR, (Schmidt, H.), 2021, Rn. 0-33.

GÁLVEZ CRIADO, A., "El derecho de cancelación del usuario de la reserva de alojamientos turísticos”, Revista de Estudios Jurídicos y Criminológicos, núm. 3, Universidad de Cádiz, 2021, págs. 65-102, DOI: http://doi.org/10.25267/REJUCRIM.2021.i3.4

GUILARTE GUTIÉRREZ, V., "Artículo 2. Arrendamiento de vivienda", en Comentarios a la Ley de Arrendamientos Urbanos, (dirs. Crespo Allué, F. y Guilarte Gutiérrez, V.), Valladolid, Thomson Reuters, 1‥ ed., 2014, págs. 29-52.

LACRUZ BERDEJO, J.L., Estudios de Derecho Privado común y foral. Tomo II, Barcelona, Bosch, 2005.

MEHLE, “§542 Ende des Mietverhältnisses”, en beck-online.GROSSKOMMENTAR, (Schmidt, H.), 2021, Rn. 0-158.

- “\$545 Stillschweigende Verlängerung des Mietverhältnisses”, en beckonline.GROSSKOMMENTAR, (Schmidt, H.), 2021, Rn. 0-14.

MOLINA ROIG, E., Una nueva regulación para los arrendamientos de vivienda en un contexto europeo, Valencia, Tirant lo Blanch, 2018.

MORENO-TORRES HERRERA, M.L. y MARTENS JIMÉNEZ, I.L., "Pasado, presente y futuro de la regulación de los arrendamientos de viviendas turísticas en el ordenamiento español”, Revista Jurídica del Notariado, núm. 112, 2021, págs. 271-312.

QUESADA SÁNCHEZ, A., "La cesión de viviendas turísticas por habitaciones: situación legal en España y propuestas razonables", Revista Crítica de Derecho Inmobiliario, núm. 783, 2021, págs. 279-313. 
QUICIOS MOLINA, S., "Capítulo II. De la duración del arrendamiento", en Propuesta de Código Civil, (Asociación de Profesores de Derecho Civil), Madrid, Tecnos, 2018, págs. 718-719.

RAMÓN CHORNET, J.C., “Artículo 1137. Concurrencia de pluralidad de acreedores o deudores", en Código Civil Comentado, (dirs. Cañizares Laso, A., De Pablo Contreras, P., Orduña Moreno, F.J. y Valpuesta Fernández, R.), Cizur Menor, Thomson Reuters Aranzadi, 2a. ed., 2016, págs. 275-281.

SIMÓN MORENO, H., "Propuestas de regulación para habitar parcialmente una vivienda", en El acceso a la vivienda en un contexto de crisis, (dir. Nasarre Aznar, S. y coord. Simón Moreno, H.), Madrid, Edisofer, 2011, págs. 225-248.

- "Las cooperativas de viviendas en régimen de cesión de uso: ¿una alternativa real a la vivienda en propiedad y en alquiler en España?", REVESCO. Revista de Estudios Cooperativos, vol. 134, 2020, e69165, DOI: https://dx.doi.org/10.5209/REVE.69165.

VALLADARES RASCÓN, E. y ORDÁS ALONSO, M., "Artículo 1. Ámbito de aplicación", en Comentarios a la Ley de Arrendamientos Urbanos, (coord.

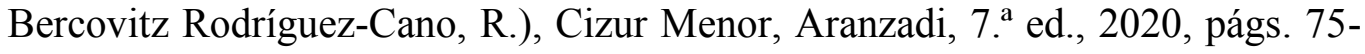
78.

- "Artículo 2.1. Arrendamiento de vivienda", en Comentarios a la Ley de Arrendamientos Urbanos, (coord. Bercovitz Rodríguez-Cano, R.), Cizur Menor,

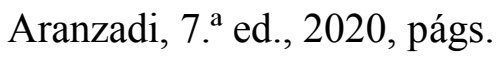

